$9-15-2020$

\title{
Empirical Data On How Investors Are Harmed When Companies Do Not Disclose Information About Violence and Lack of Indigenous Consent
}

Shin Imai

Osgoode Hall Law School of York University, simai@osgoode.yorku.ca

Sarah-Grace Ross

Source Publication:

Submission to the Independent Capital Markets Modernization Task Force (Ontario)

Follow this and additional works at: https://digitalcommons.osgoode.yorku.ca/scholarly_works

Part of the Business Organizations Law Commons

\section{Repository Citation}

Imai, Shin and Ross, Sarah-Grace, "Empirical Data On How Investors Are Harmed When Companies Do Not Disclose Information About Violence and Lack of Indigenous Consent" (2020). Articles \& Book Chapters. 2818.

https://digitalcommons.osgoode.yorku.ca/scholarly_works/2818

This Article is brought to you for free and open access by the Faculty Scholarship at Osgoode Digital Commons. It has been accepted for inclusion in Articles \& Book Chapters by an authorized administrator of Osgoode Digital Commons. 


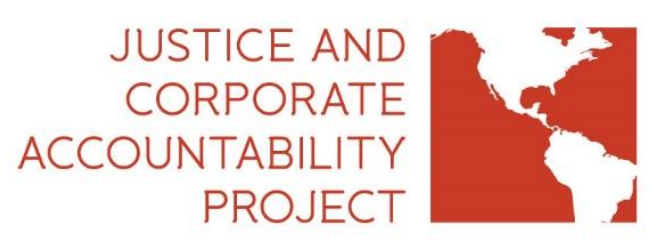

\section{Empirical Data \\ On How Investors Are Harmed When Companies Do Not Disclose Information About Violence and Lack of Indigenous Consent}

Submission to the Independent Capital Markets Modernization Task Force (Ontario)

September 15, 2020

Shin Imai

Sarah-Grace Ross

Justice and Corporate Accountability Project

Room 3015

Osgoode Hall Law School of York University

4700 Keele Street

Toronto M4K 1 M6

Email: info@justice-project.org

Website: Justice-project.org

Twitter: @JCAPosgoode 


\section{Table of Contents}

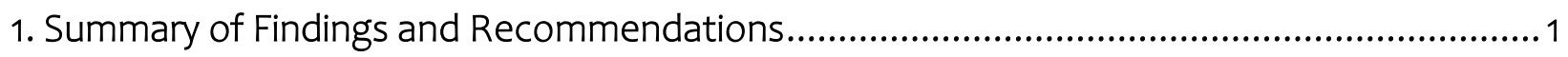

2. The Justice and Corporate Accountability Project (JCAP) .....................................................

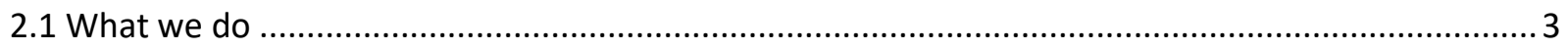

2.2 Empirical studies on JCAP complaints about lack of company disclosure of social license, Indigenous consent and violence ..............................................................................................

3. Why do we conclude that information about violence and Indigenous consent are

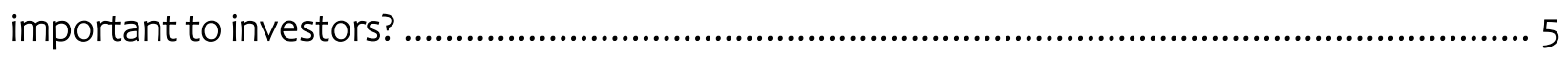

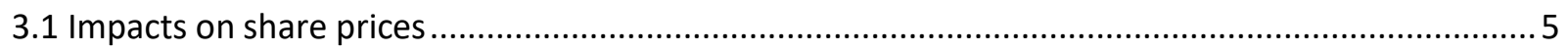

3.2 Divestment by institutional shareholders ................................................................................. 8

3.3 Subsequent Tahoe owner addresses issues raised in a JCAP complaint, January 2019..................... 8

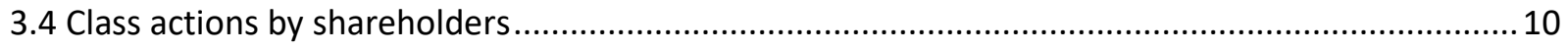

4. Tahoe Resources: A sad case for investors, a tragic case for Guatemalan victims ................10

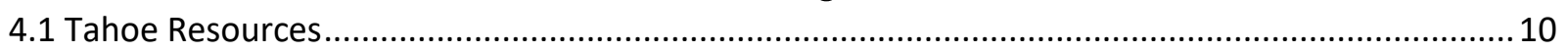

4.2 Community Opposition at Escobal Mine in Guatemala …………………………………….....11

4.3 Violence at Escobal Mine......................................................................................................... 12

4.4 Materiality and Financial Impact of the Human Rights Abuses at Escobal ....................................14

4.4.1 The Norwegian Government Pension Fund Global ..............................................................14

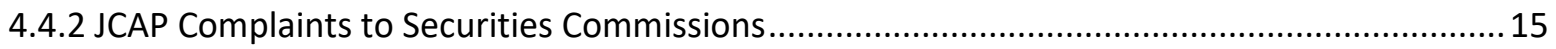

5. Problems with the status quo: Inadequate Responses from Regulators and Vague National Instrument Guidance ............................................................................................................. 17

5.1 Lack of Response from Regulators .......................................................................................

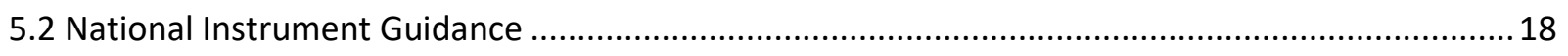

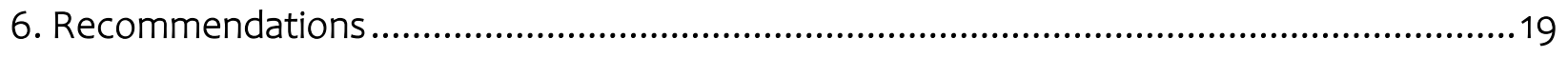

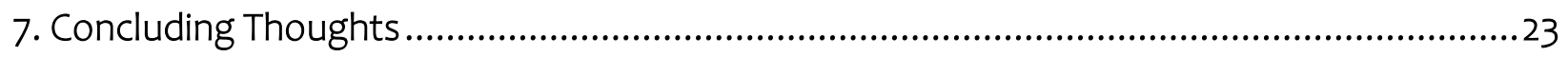

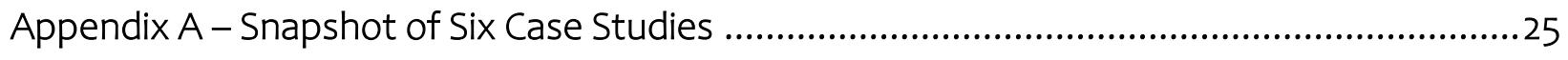

Appendix B - Excerpt from Canada Brand report on disclosures made by companies with respect to violence associated with their mines ……........................................................... 38

\section{We welcome comments}

We are happy to incorporate comments, critiques or correction of factual errors into future versions of this report at https://papers.ssrn.com/sol3/papers.cfm?abstract_id=3690013 


\section{Summary of Findings and Recommendations}

The Justice and Corporate Accountability has filed a number of complaints to the Ontario Securities Commission, the British Columbia Securities Commission and the United States Securities and Exchange Commission relating to the failure of Canadian mining companies to disclose information on community conflict, violence and Indigenous consent. We have also studied violence associated with 28 Canadian mining companies in Latin America and recorded company disclosure of violence.

\section{Empirical Findings}

We found four indicia that showed that the information disclosed in our complaint (but not disclosed by the companies) was important material information relating to the health of the company.

1. Media coverage of JCAP's complaints were followed by a drop in the share price.

2. Institutional investors divested specifically because of concerns with the human rights record of the mine.

3. A subsequent owner of mine immediately addressed concerns raised in our complaint.

4. Shareholders began class action law suits based on a company's failure to disclose material information.

In our study of violence associated with Canadian mining companies in Latin America, we found that publicly listed companies reported only $24.2 \%$ of the deaths and $12.3 \%$ of the injuries listed in the report.

\section{Problems}

In none of the six complaints did the regulator take any enforcement action, or even require disclosure by the companies. We see this partly as a problem of the lack of attention by the regulator and partly because of the vagueness of the guidance provided in the National Instruments.

\section{Recommendations}

We adopt the general recommendations made by the Canadian Lawyers Association for International Human Rights (CLAIHR) to the is commission.

1. Saliency is an appropriate lens for assessing the materiality of human rights impacts 
2. Ontario should keep pace with disclosure trends toward mandating reporting human rights due diligence and stakeholder impacts

We add two recommendations applicable to specifically to extractive companies.

3. Extractive companies should have more explicit guidance related to disclosure of violence and human rights issues, and securities regulators should be required to enforce disclosures on these issues.

4. There should be specific disclosure requirements relating to free, prior, and informed consent of Indigenous peoples (FPIC) for extractive companies, and securities regulators should be required to enforce these disclosure requirements.

We address two potential objections to our recommendation for more stringent disclosure requirements.

1. More fulsome disclosure will not create a burden on reporting companies because they already know, or ought to know, about violence, Indigenous consent and the human rights impact of their projects.

2. The existence of Corporate Social Responsibility policies by companies does not obviate the necessity of disclosing violence, Indigenous consent and the human rights impact, because the voluntary and unregulated nature of CSR means that these policies could actually mislead investors into thinking that there was social license in cases where none existed. 


\section{The Justice and Corporate Accountability Project $(J C A P)$}

\subsection{What we do}

The Justice and Corporate Accountability Project (JCAP) is directed by a small group of volunteer lawyers and law professors. We are based at Osgoode Hall Law School and Thompson Rivers Law School.

The focus of our work is on the impact of Canadian extractive industries on Indigenous and campesino ("peasant") communities, mostly in Latin America, but also in Canada and Kenya. As we explain below, no one disputes the fact that there is a great deal of conflict associated with extractive industries and that there may be a great deal of community resistance to these projects. JCAP began in 2012 by looking at national and international human rights instruments to address allegations of human rights violations. After quickly realizing that these avenues have been ineffective in making corporations accountable, JCAP turned toward exploring accountability mechanisms embedded in corporate law and securities law.

\subsection{Empirical studies on JCAP complaints about lack of company disclosure of social license, Indigenous consent and violence}

Beginning in about 2012, JCAP began exploring the continuous disclosure requirements in securities legislation and how securities commissions react to complaints about non-disclosure. In each case, JCAP represented communities that had serious conflicts with a Canadian mining company. The work entailed researching disclosures made by the companies in their SEDAR filings, as well as any media releases contemporaneous to the conflicts. When we were confident that adequate disclosures were not made, we would file a complaint, and the communities and their supporters would inform the media of the complaint. We would then record any impact on stock prices contemporaneous to the publicizing of the complaint.

In this submission, we will describe the results of six complaints regarding the lack of disclosure by Excellon Resources (TSX:EXN) in Mexico, Northern Dynasty (TSX:NDM) in Alaska, and four complaints relating to Tahoe Resources (TSX:THO) in Guatemala. In Appendix A we provide a summary of the cases showing when the complaint was filed, whether there were any media reports, and what happened to the stock prices. Copies of the six complaints can be found online. ${ }^{1}$

\footnotetext{
1 JCAP's 2012 complaint regarding Excellon; JCAP's 2019 complaint regarding Northern Dynasty; JCAP's 2013 complaint regarding Tahoe; JCAP's 2016 complaint regarding Tahoe; JCAP's 2017 complaint to the BCSC regarding Tahoe; JCAP's 2019 complaint regarding Tahoe.
} 
Also of relevance is JCAP's three-year study called "The Canada Brand: Violence and Canadian mining companies in Latin America", ${ }^{2}$ which tracked reports in the media and in blog posts of violence at mining projects, over a 15 -year period. This work was undertaken by Spanishspeaking law students from across Canada. The report only includes incidents that could be corroborated by at least two independent sources and does not attribute fault for the violence. We found:

- 28 Canadian companies were involved in incidents;

- 44 deaths, 30 of which we classify as "targeted";

- 403 injuries, 363 of which occurred during protests and confrontations;

- 709 cases of "criminalization", including legal complaints, arrests, detentions and charges; and,

- a widespread geographical distribution of documented violence: deaths occurred in 11 countries, injuries were suffered in 13 countries, and criminalization occurred in 12 countries.

The second part of the Canada Brand report documented the responses by mining companies to these incidents in their Annual Information Forms, their quarterly Management Discussion and Analysis reports, in continuous disclosure documents, and in press releases. Our research showed that Canadian companies that are listed on the Toronto Stock Exchange largely ignored these incidents. Between 2000-2015:

- publicly listed companies reported only $24.2 \%$ of the deaths and $12.3 \%$ of the injuries listed in this report; and,

- larger companies tended to report incidents in general terms, using blanket statements, whereas smaller companies tended to report the incidents in more detail.

In Appendix B we have attached an excerpt from the Canada Brand report that details our analysis of mining company disclosures.

This lack of disclosure may partly be explained by the lack of any meaningful guidance in the National Instruments 51-102 (continuous disclosure) and in the mining-specific NI 43-101. However, as shown in the case studies below, the lack of guidance is irrelevant in determining whether the missing information was material information for shareholders.

2 Imai, Shin and Gardner, Leah and Weinberger, Sarah, "The 'Canada Brand': Violence and Canadian Mining Companies in Latin America" (December 1, 2017) Osgoode Legal Studies Research Paper No. 17/2017 at 40. 


\section{Why do we conclude that information about violence and Indigenous consent are important to investors?}

The current stock price is determined by investor expectations about the future value of the stock. Data or information, therefore, that informs expectations about those future benefits may be relevant to an investment decision and therefore material to an investor.

The six case studies in Appendix A reveal that the undisclosed information was material to shareholders, as evidenced by the drop in the share price, divestment, public acknowledgement of the problem by the company and the institution of shareholder class actions.

\subsection{Impacts on share prices}

In four of the six case studies, there was a drop in the stock after our disclosure complaint was publicized. Acknowledging that there are many reasons why stock prices fluctuate, we used a $10 \%$ drop as the threshold to signify a significant variation. We related the time of the drop to news reports publicizing our complaints, and we researched whether there were other contextual events around the mine that could explain the fluctuation.

(i) Excellon Resources - July, 2012

Excellon Resources is incorporated in Ontario and operates the La Platosa silver mine in Mexico. The mine signed a contract for use of the land from the communal landowners of the property. A dispute developed over issues related to a union and issues related to the land use contract, and the mine was blockaded by protestors. Excellon reported the conflict on July 9, 2012, and threatened legal action. At that time, the stock was valued at $\$ 3.45$, but it began falling in the next couple of days to under $\$ 2.85$. However, on Friday July 13, there was a small uptick in the price to around $\$ 2.95$.

The company had not disclosed, however, that the core of the dispute related to the possible rescission of the permission to use the land on which the mine was located. On Monday July 16, JCAP filed a complaint to the Ontario Securities Commission (OSC) on behalf of the Mexican landowners and provided documentary evidence of the land dispute. When this complaint became public, the stock fell again. On the next day, July 17, headlines announced "Excellon's stock plummets over 11\%" and "Securities Commission asked to investigate Excellon disclosures". At the close of July 17, the stock fell to about $\$ 2.45$, a drop of about $17 \%$. At the time of writing this submission, on September 4, 2020, Excellon stock was trading at $\$ 0.97$. 
The fact that the price fell after the media reports made explicit mention of our complaint to the OSC and its contents regarding the potential rescission of the land use contract suggests that the information in the complaint contributed to the drop in price.

(ii) Tahoe Resources - May, 2013

Tahoe Resources was a company incorporated in British Columbia with its headquarters in the United States. Its main asset was the Escobal silver mine in Guatemala. Tahoe had a very violent relationship with the surrounding communities. There were many protests and assassinations of community leaders. On April 27, 2013, a group of farmers from the area gathered peacefully in front of the gates of the mine for a symbolic protest. While they made no attempt to enter the mine site, within four minutes of their arrival, heavily-armed private security guards stormed out of the gates and began shooting without warning. The company's security camera shows that the guards continued to shoot protesters in the back as they fled. ${ }^{3}$

On May 30, 2013, JCAP filed a complaint to the Ontario Securities Commission on behalf of the Committee in Defence of Life and Peace in Guatemala and MiningWatch Canada. The complaint pointed out that Tahoe had not disclosed key facts about the arrest of the head of its security, Alberto Rotondo, and the fact that he had ordered that the protesters be shot. After media reports of our complaint, the stock began to drop. In the three weeks following JCAP's complaint, Tahoe's stock on the NYSE fell by $11.81 \%$.

(iii) Tahoe Resources - August, 2016

Tahoe was very upbeat about its community relations in Guatemala in its annual filings and produced a special report showing the benefits that it had been bringing to people in the area. At

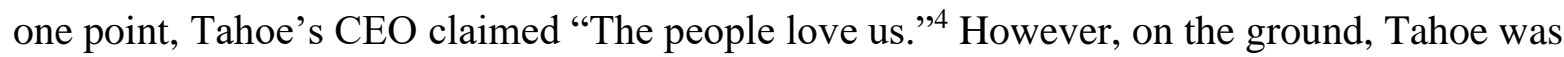
experiencing so much community resistance that it could not even hook up to the local power grid and was forced to run on diesel. ${ }^{5}$

On August 11, 2016, JCAP submitted a complaint to the United States Securities and Exchange Commission on behalf of the Network in Solidarity with the People of Guatemala and the Catholic Church Committee for the Defense of Nature in Guatemala, showing that Tahoe had not disclosed the extent of the community opposition nor that it had brought lawsuits to stop the community plebiscites on mining. The company also brought a lawsuit against the government of Guatemala for failing to provide more protection against protests. In particular, we indicated

\footnotetext{
${ }^{3}$ See security video of the shooting here: https://tahoeontrial.net/2015/11/19/security-footage-april-27-2013/.

${ }^{4}$ Justice and Corporate Accountability Project, "Request to Investigate Tahoe Resources for Failure to Disclose Material Information" (August 8, 2016) at 10.

${ }^{5}$ Justice and Corporate Accountability Project, "Request to Investigate Tahoe Resources for Failure to Disclose Material Information" (August 8, 2016) at 11.
} 
that the local Xinca Indigenous people were adamantly opposed to the mine, and that one of its leaders had been assassinated on the way home from a community plebiscite on mining. At the time of the complaint's filing, there had been at least three targeted assassinations of individuals involved in organizing plebiscites on mining. (More killings have occurred since.)

In the nine business days following media reports on JCAP's complaint on August 11, Tahoe's TSX stock dropped by $13.24 \%$. It is noteworthy that on August 8, 2016, Zacks Investment Research reported that analysts estimated an earnings beat, which would cause stock prices to rise following Tahoe's next quarterly report. ${ }^{6}$ On August 10, Tahoe announced a very successful quarter with earnings that beat expectations, resulting in a rise of nearly $6 \% .^{7}$ Despite Tahoe's much-anticipated and well-received quarterly report, the stock immediately began to fall the following day, August 11. when JCAP's complaint was publicized, and continued to drop in the weeks that followed. There were no other announcements or events that would explain the sudden drop in the price.

(iv) Tahoe Resources - May, 2017

In May 2017, JCAP filed a complaint with the British Columbia Securities Commission on Tahoe's failure to disclose the extent of community opposition to the mine, and in particular the lack of consent of the Indigenous Xinca people. This was substantially the same complaint that JCAP had filed with the US Securities and Exchange Commission in 2016. We did not publicize this complaint and there was no discernable change in the stock price at that time.

However, it became apparent that the information with respect to the opposition of the Xinca Indigenous people was material to the operations of the mine because on July 5, 2017, the Constitutional Court of Guatemala suspended the mine for lack of consultation with the Indigenous people. With the news of the mine's suspension, Tahoe's stock started to drop dramatically and institutional investors began divesting. In the two days after the court decision, Tahoe's stock fell over 33\% and remained at this level for the following month. In fact, Tahoe's stock never recovered to pre-July 5 levels.

This is a case where the exception proves the rule - there was no publicity of JCAP's complaint and no impact on the stock price. However, the materiality of the information became obvious when the lack of consent of the Indigenous people closed the mine and investors suffered loss.

\footnotetext{
${ }^{6}$ Zacks Investment Research, "Should You Sell Tahoe Resources (TAHO) Before Earnings?” (August 8, 2016).

7 Northern Miner, “Tahoe’s Q2 earnings beat expectations” (August 10, 2016).
} 
(v) Northern Dynasty Minerals - April, 2019

Northern Dynasty is incorporated in British Columbia and in 2019 was seeking approval of a project in Alaska. Northern Dynasty promoted its project as a world class find with 11 billion tonnes of mineral resources. However, Northern Dynasty hid the fact that it was only applying for a permit to access 1.17 billion tonnes and that the Bristol Bay Native Corporation was opposed to the project and had refused to grant access to the proposed pipeline. On behalf of environmental NGO Earthworks, JCAP filed a complaint to the BC Securities Commission and the United States Security and Exchange Commission on April 30, 2019.

There were immediate reports in the business press, including BNN Bloomberg and Mining Weekly, referring to the complaint. In the seven business days after JCAP filed its report, Northern Dynasty's NYSE stock dropped by $22.22 \%$ and its TSX stock dropped by $24.68 \%$.

\subsection{Divestment by institutional shareholders}

Major divestments by institutional investors illustrate the importance of Tahoe's failure to disclose material information on community opposition. The $\$ 850$ billion Norwegian Government Pension Fund divested in January 2015 based on discrepancies between information disclosed by Tahoe and the information reported by the United Nations High Commissioner on Human Rights and Amnesty International. The Norwegian Council on Ethics, which advised the Fund, engaged with Tahoe and concluded that, "[Tahoe's] replies to the Council make it difficult for the Council to conclude that the company's systems and strategies are suited to reveal, prevent and compensate for human rights violations connected to the operation." JCAP's 2016 complaint to the SEC outlined a number of areas where the Council was not satisfied with Tahoe's official disclosures. ${ }^{9}$ At around the same time, the Canada Pension Plan Investment Board also divested, as did the Dutch pension fund, Pensioenfonds PGB.

These divestments show that institutional investors who have the resources to conduct their own investigations can protect themselves. Retail investors, however, lack this capacity and must rely on companies to be forthright about human rights challenges.

\subsection{Subsequent Tahoe owner addresses issues raised in a JCAP complaint, January 2019}

Late in December 2018, after Tahoe's Escobal mine had been closed for a year and a half, Pan American Silver, another Canadian company, decided to purchase Tahoe. The purchase price in

\footnotetext{
${ }^{8}$ Council on Ethics to the Government Pension Fund Global, "Recommendation to exclude Tahoe Resources Inc. from the investment universe of the Government Pension Fund Global" (April 8, 2014) at 1.

${ }^{9}$ See pages $20-27$ of the complaint.
} 
2019 was around \$4 USD, a major drop from prices in 2013 when Tahoe was trading at $\$ 16.74$ USD.

On January 3, 2019, JCAP filed a complaint on behalf of Earthworks, Maritimes-Guatemala Breaking the Silence Network and MiningWatch Canada, organizations that work with the Xinka communities in the vicinity of the Escobal project of Tahoe Resources. The complaint requested the British Columbia Securities Commission to investigate whether Tahoe misstated and omitted material facts which were necessary for the shareholder vote, including Indigenous Xinca opposition to the consultation process and Tahoe's misleading and unrealistic statements about the mine reopening in December 2019. ${ }^{10}$ Tahoe also failed to disclose that the Constitutional Court nullified Tahoe's last remaining exploratory license, presenting potentially insurmountable barriers to Tahoe's expansion plans.

JCAP's complaint received significant news coverage. ${ }^{11}$ There did not appear to be a significant impact on Tahoe's stock prices as the transfer of ownership to Pan American Silver was well on its way. However, Pan American Silver immediately took steps to address the situation at the mine. First, it quickly discarded a prediction that the mine would reopen in December 2019, in a new release.

We agree that proper consultation with Indigenous groups and broader engagement with communities of interest are important to gaining the social acceptance for the Escobal mine to re-open. .... We have been clear that this process will take time and we have never set a timeline for the restart of the Escobal mine. ${ }^{12}$

Second, Pan American also settled the lawsuit launched by the farmers shot in the back by Tahoe security forces and provided an apology. Pan American president and CEO Michael Steinmann said in a news release:

When we completed the acquisition of Tahoe, we made it a priority to reach out and make a constructive proposal to resolve the matter amicably rather than continue with the litigation. We sincerely hope that this resolution provides some measure of closure. ${ }^{13}$

These actions by Pan American show that the information provided in the JCAP complaints were material to the operations of the mine.

\footnotetext{
${ }^{10}$ In fact, the mine remains closed as of September 2020 and there is no planned date for re-opening.

${ }^{11}$ BIV, "Activists file securities complaints against Vancouver miners", (January 3, 2019); Toronto Star, "Advocates call for investigations into Vancouver mining companies for reportedly omitting facts", (January 3, 2019); Financial Post, "Days before merger, complaints filed asking for investigation of Pan American and Tahoe Resources" (January 3, 2019); CIM, "B.C. Securities Commission asked to investigate Tahoe and Pan American days before acquisition vote" (January 3, 2019).

${ }^{12}$ Canadian Lawyer, "Securities commissions asked to investigate ahead of mining companies merger" (January 3, 2019).

${ }^{13}$ BIV, “UPDATED: Pan American closes Tahoe's six-year legal battle with Guatemalan protestors” (July 30, 2019.

9|P a g e
} 


\subsection{Class actions by shareholders}

Another indicator of materiality is whether the information in play becomes the subject of shareholder class action suits. In the case of Tahoe, after the sudden drop in the share price when the mine was suspended, JCAP received calls from half a dozen law firms in Canada and the United States. These firms were seeking details on the 2017 JCAP complaint highlighting the lack of Indigenous consent. These suits are based directly on the lack of disclosure by Tahoe as a cause for the losses suffered by investors.

\section{Tahoe Resources: A sad case for investors, a tragic case for Guatemalan victims}

The following section of the submission examines the Tahoe case study in more detail, tracking company disclosure trends over the course of eight years regarding allegations of human rights abuses, kidnappings, shootings, murders, and cover-ups, as well as significant community opposition. The purpose of the case study is to provide insight into the materiality of these issues by tracking how Tahoe refused to acknowledge or address problems with human rights and community opposition, ultimately leading to its downfall on the stock market and corporate takeover.

\subsection{Tahoe Resources}

Tahoe Resources Inc. was incorporated in 2009 in British Columbia and headquartered in the United States. It did not have employees, an office, or even an authentic address in Canada. Their BC address was in fact the address of their law firm. ${ }^{14}$ In its 2015 Short Form Prospectus, Tahoe disclosed that "a majority of our directors are in the United States and that the business is administered principally from Nevada." 15

This arrangement is popular for taking advantage of Canada's relaxed securities regulations. Tahoe explained its decision by saying that the "regulatory and compliance costs to us under U.S. securities laws as a U.S. domestic issuer will be significantly more than the costs incurred as a Canadian foreign private issuer." 16

\footnotetext{
${ }^{14}$ Shin Imai et al, "The 'Canada Brand': Violence and Canadian Mining Companies in Latin America" (December 1, 2017) Osgoode Legal Studies Research Paper No. 17/2017, at 40.

${ }^{15}$ Tahoe Resources Inc., Short Form Prospectus (June 23, 2015) at 27.

16 Tahoe Resources Inc., Short Form Prospectus (June 23, 2015) at 27.
}

$\mathbf{1 0} \mid \mathrm{P}$ a g e 


\subsection{Community Opposition at Escobal Mine in Guatemala}

A few months following its incorporation, Tahoe purchased the Escobal mining project from Goldcorp in June 2010. From the very start, the Escobal project was mired in conflict. Local communities disapproved of the environmental and social impacts of the project and were vocal about Tahoe's failure to adequately consult. While many of the complaints about the impacts of the project pre-dated Tahoe's ownership, the community opposition increased under Tahoe. Local communities held protest marches and referendum votes using secret ballots which resoundingly rejected the Escobal proposal. ${ }^{17}$ Despite consistent community opposition and clear referendum results, Tahoe remained steadfast in telling the public that it had obtained social license from communities to operate the mine. In an interview with the Business News Network in January 2015, Tahoe's CEO Kevin McArthur said, "the communities love us." ${ }^{\text {" Tahoe }}$ claimed that seven out of nine local communities supported the mine, despite many of these communities having pulled their support. ${ }^{19}$

Tahoe went to great lengths to attempt to invalidate the community referendums, also known as plebiscites, by bringing lawsuits that would prevent votes from taking place and attempting to invalidate results that were unfavourable. ${ }^{20}$ In 2012, in response to a lawsuit by Tahoe requesting that a plebiscite be stopped, Guatemala's Constitutional Court called plebiscites an important mechanism for a democratic regime. ${ }^{21}$ The outcomes of the plebiscite referendums were clear:

- A 2011 plebiscite in Santa Rosa de Lima resulted in 95.69\% of votes against mining in the area. $^{22}$

- A 2011 plebiscite in Casillas resulted in $98.6 \%$ of votes cast being against mining. ${ }^{23}$

- A 2012 plebiscite in Mataquescuintla resulted in $96.5 \%$ of votes cast being against mining. ${ }^{24}$

- A 2015 plebiscite in San Juan Tecuaco resulted in 98\% voting against mining in their region. ${ }^{25}$

\footnotetext{
${ }^{17}$ MiningWatch Canada and NISGUA, “Tahoe Resources Investor Alert Calls Guatemala Project a Dangerous Investment," (May 8, 2013).

${ }^{18}$ Business News Network (BNN), “Tahoe CEO: Sure I love silver but I'm making \$1B bet on gold”, (Feb 9, 2015).

${ }^{19}$ Tahoe Resource Inc., Tahoe Resources Inc.'s Response to Recent Baseless and Irresponsible Accusations in "Tahoe on Trial," (December 22, 2015).

${ }^{20}$ Tahoe Resource Inc., Tahoe Resources Inc.'s Response to Recent Baseless and Irresponsible Accusations in "Tahoe on Trial”, (December 22, 2015).

${ }^{21}$ Corte de Constitucionalidad de Guatemala, Expedientes Acumulados 2432-2011 y 2481-2011, December 5, 2012.

${ }^{22}$ Corte de Constitucionalidad de Guatemala, Expedientes Acumulados 2432-2011 y 2481-2011, December 5, 2012.

${ }^{23}$ Corte de Constitucionalidad de Guatemala, Expediente 4672-2011, February 13, 2014.

${ }^{24}$ Instituto Nacional de Estadistica, Guatemala: Estimaciones de la Población total por municipio. Período 20082020 (al 30 de junio).

${ }^{25}$ Truth Out, “Guatemalans are Taking Their Democracy Back”, (June 13, 2015).
} 
Each of these plebiscites were challenged in court by Tahoe, its subsidiary company (Mineral San Rafael "MSR"), or the Guatemala Chamber of Commerce, through either attempts to invalidate their results or attempts to prevent the referendums from taking place at all.

In 2012, Tahoe and MSR escalated their efforts by suing the President of Guatemala and other government entities for protection against community opposition. MSR secretly filed the lawsuit, claiming that community protests had impeded its work and accusing Guatemalan government entities of failing to protect the mine. ${ }^{26}$ The Constitutional Court dismissed the lawsuit. At no point did Tahoe disclose this litigation or its contents to shareholders. Tahoe also failed to disclose to shareholders that it worried that the community opposition was impeding work at the mine. In fact, Tahoe's public messaging was in stark contrast to the contents of the litigation. Tahoe continued to claim that community opposition was small, very limited, and did not have "a material effect on operations, financial position, cash flow or results.",27

\subsection{Violence at Escobal Mine}

There have been a number of kidnappings, shootings, murders, and cover-ups of local community members who protested the Escobal mine. For the first three incidents listed below, no suspects have been identified. Tahoe denies any involvement, though community members blame Tahoe.

1. In March 2013, four members of the Xinca Parliament, which represents the local Indigenous population, were abducted on their way home from a plebiscite in Volcancito where more than 99\% of people voted against Escobal. The Xinca Parliament had vocally opposed the mining operation and demanded consultations before licenses were granted. ${ }^{28}$ One of the Xinca leaders, Exaltación Marcos Ucelo, was found dead the next day.

2. Sixteen-year old Topacio Reynoso, a youth organizer against the mine, was assassinated and her father badly injured in an attack on their car in Mataquescuintla in April 2014. ${ }^{29}$ Her father was shot at again in October 2015 as he and two companions were leaving the office of the mayor of Mataquescuintla. ${ }^{30}$ Topacio was a youth organizer for the plebiscite campaign.

3. In April 2015, Telésforo Odilio Pivaral González, a member of the Committee in Defense of Life and Peace in San Rafael Las Flores, which opposes the mine, was assassinated at a bus stop near his home in Volcancito. ${ }^{31}$

${ }^{26}$ Corte de Constitucionalidad de Guatemala, Expediente 2728-2012, June 28, 2012.

27 Tahoe Resources Inc., 2011 Annual Information Form (March 8, 2012) at 19-20.

${ }^{28}$ Council on Ethics for the Government Pension Fund Global, Annual Report, 2014, (December 31, 2014$)$ at 172.

${ }^{29}$ Nina Lakhani, "Clashes as Guatemalan communities fight mine", $B B C$ (June 6, 2014).

${ }^{30}$ Prensa Libre, "Nuevo ataque contra dirigente anti minería", (October 17, 2015).

${ }^{31}$ Noticias, "Miembro de Resistencia en San Rafael Las Flores fue asesinado", (April 5, 2015). 
4. On April 27, 2013, members of Tahoe's security personnel shot six farmers and one student. The group had gathered together on private property outside of the mine's property to peacefully demonstrate against the Escobal project. Tahoe claimed that the protest turned "hostile" and the "security force used tear gas and rubber bullets to repel the protestors at the mine gate." 32 Unbeknownst to Tahoe, telephone conversations of their head of security, Alberto Rotondo, had been wiretapped due to suspicions of his involvement in a prior incident of violence. The wiretapped conversations include Rotondo ordering the shooting of the protestors and then conspiring to cover up the evidence and fabricate a story of the protestors' attack.

Security video obtained from the company shows that there were about twenty protesters, but they made no attempt to enter the open gate nor is there any indication that traffic was impeded. ${ }^{33}$ The video shows no provocation on the part of the protestors as bullets were fired towards them. Within four minutes of the arrival of the protesters, heavily armed security personnel with shields, helmets and bullet proof vests charged the group. As the protestors fled, they were shot in the back. Seven of the protesters were injured. ${ }^{34}$

Rotondo was arrested at an airport when fleeing the country in an attempt to "leave Guatemala for a while" after ordering that the protesters be killed. ${ }^{35}$ Rotondo was charged with obstruction of justice and assault. Juan Pablo Oliva Trejoa, an advisor to Rotondo, was later charged with concealment of evidence, aiding Rotondo in the shooting of protestors, and assisting in Rotondo's attempted escape from the country.

In the wake of this event, Tahoe repeatedly blamed protestors for behaving violently while downplaying the actions of their security personnel. Tahoe issued frequent press releases following the event, though none of them disclosed the arrests of Rotondo or Trejo, the incriminating wiretap evidence, or the tactics used by their security personnel. ${ }^{36}$ However, these troubling facts were covered in major news publications. ${ }^{37}$

\footnotetext{
32 Tahoe Resources Inc., Tahoe Clarifies Reports Regarding Incidents Near Escobal Project, (May 1, 2013).

33 Tahoe Resource Inc., Tahoe Resources Inc.'s Response to Recent Baseless and Irresponsible Accusations in "Tahoe on Trial", (December 22, 2015).

34 Tahoe on Trial, "Security Footage Outside Escobal Mine - April 27, 2013”, (November 19, 2015).

35 SigloXXI, "Rotondo ordenó: Maten a esos hijos de la gran...” (May 9, 2013).

36 Yahoo! Finance, "Tahoe Clarifies Reports Regarding Incidents Near Escobal Project” (May 1, 2013); Tahoe Spokesperson on CBC News, CBC Radio 1, May 4, 2013.

${ }^{37}$ iPolitics, "Canadian mine's security staff detained as deadly protests trigger crackdown in Guatemala” (May 3, 2013); Yahoo! Finance "Complaint asks Ontario Securities Commission to Investigate Tahoe Resources" (June 3, 2013); Proactive Investors (June 3, 2013) "Tahoe trades down as complaint tied to violence at Guatemalan mine submitted to OSC".
}

$\mathbf{1 3}$ | $\mathrm{P}$ a g e 


\subsection{Materiality and Financial Impact of the Human Rights Abuses at Escobal}

While the human rights abuses outlined above went unaddressed by Tahoe, the connection of these events to the Escobal mine and Tahoe personnel has been sufficient to lead to major concerns from investors. There is evidence of the financial impact that these events have had on Tahoe, from major investment funds divesting their interests to substantial and permanent drops in Tahoe's stock performance. Given the importance of these human rights issues on Tahoe's financial performance, these incidents should be considered material information that require timely disclosure by securities regulators.

\subsubsection{The Norwegian Government Pension Fund Global}

Norway's Government Pension Fund Global is the largest fund of its kind in the world with a market value in 2014 of over \$USD 850 billion. To guide the fund in its investment decisions, the Ministry of Finance has a Council on Ethics that provides advice to the Norwegian Pension Fund on whether certain investments meet ethical criteria set out in its governing documents.

In 2013, the Pension Fund had NOK 86.5 million invested in Tahoe's stock. The Council on Ethics decided to assess their investment in Tahoe, having grown concerned about the serious human rights violations connected to the Escobal mine. In 2014, the Council recommended that Tahoe be excluded from their investments. ${ }^{38}$ In its review of human rights issues relating to Tahoe, the Council gathered information from several sources, including reports by the United Nations High Commissioner on Human Rights and Amnesty International and from Tahoe itself. Not only did Tahoe fail to provide supporting evidence for their claims that they were not in any way involved in local violence surrounding the mine, the Council reached a number of conclusions that contradicted Tahoe's assertions. They are as follows:

- Tahoe asserted that, based on the findings of their own investigation, the violence around Escobal mine was the fault of external criminal groups and that the results of plebiscite votes could not be relied upon. Tahoe would not provide the investigation to the Council. $^{39}$

- Tahoe sought to reassure the Council that they met and/or exceed international standards and guidelines; the Council disagreed. ${ }^{40}$

- Tahoe insisted that they have a corporate social responsibility policy, but would not disclose these policies to the Council based on confidentiality. ${ }^{41}$

- Tahoe did not comply with the Council's request for information on the company's rules of conduct, particularly relating to security personnel.

\footnotetext{
${ }^{38}$ Council on Ethics for the Government Pension Fund Global, Annual Report, 2014, (December 31, 2014).

${ }^{39}$ Council on Ethics for the Government Pension Fund Global, Annual Report, 2014, (December 31, 2014) at 167, 176.

${ }^{40}$ Council on Ethics for the Government Pension Fund Global, Annual Report, 2014, (December 31, 2014 ) at 179.

${ }^{41}$ Council on Ethics for the Government Pension Fund Global, Annual Report, 2014, (December 31, 2014 ) at 179.
} 
- Tahoe did not comply with the Council's request for information about the death of the Xinca Parliamentarian.

The Council concluded that Tahoe's replies made it difficult to ascertain whether human rights violations connected to the mine were being prevented and addressed, and consequently it recommended divestment.

Norway's pension fund was not the only fund to divest from Tahoe around this time. The Dutch Pension Fund - the Netherlands' Pensioenfonds - divested from Tahoe on the basis of the human rights violations in connection with Escobal as did the Canada Pension Plan Investment Board. ${ }^{42}$

\subsubsection{JCAP Complaints to Securities Commissions}

JCAP was retained by organizations working with the communities in Guatemala to make investors aware of the violence surrounding the project. Over the course of 2013-2019, JCAP filed four separate complaints to securities regulators requesting investigations. JCAP filed its first complaint to the Ontario Securities Commission on May 30, 2013, requesting an investigation into whether Tahoe breached section 75(1) of the Securities Act, R.S.O. 1990, c. S.5. Specifically, JCAP's complaint highlighted how Tahoe downplayed the seriousness of the protestor shooting and made misleading statements about the criminal charges against Rotondo. Examples of Tahoe's misleading statements include downplaying their head of security being detained, failing to state that Rotondo was charged or that he was attempting to flee the country, as well as making inaccurate statements about the protestors and actions of security personnel. Once JCAP's complaint to the OSC was public on May 30, Tahoe's stock experienced a significant drop despite having been on an upward trajectory. In the three weeks following JCAP's complaint, Tahoe's stock on the NYSE dropped by $11.81 \%$.

This same pattern was repeated in 2016 when JCAP filed a complaint to the US Securities and Exchange Commission requesting an investigation into whether Tahoe continued to misstate community opposition to Escobal, failed to disclose their lawsuit against the Guatemalan government regarding protection from protestors as well as at least four lawsuits aimed at stopping and invalidating community votes about the mine, and failing to disclose material information about human rights violations, such as the kidnapping and murder of the Xinca leader and the shooting at protestors. Following JCAP's complaint and the media attention received in major news publications, Tahoe's stock dropped by $13.24 \%$ in the nine business days following the complaint. Most interestingly, this drop followed an announcement by Tahoe of a very successful quarter in which earnings beat expectations. Despite Tahoe's much-anticipated and well-received quarterly report, the stock immediately began to fall on August 11, 2016, when JCAP's complaint was publicized, and continued to drop in the weeks that followed.

\footnotetext{
${ }^{42}$ Facing Finance, “Tahoe Resources: Licence Suspended for Escobal Mine” (August 21, 2017).
} 
In 2017, JCAP filed yet another complaint, this time to the British Columbia Securities Commission, flagging the same misstated facts and failure to disclose as the 2016 complaint to the US Securities and Exchange Commission. On July 5, 2017, the Constitutional Court in Guatemala suspended Tahoe's operations at the Escobal mine for failing to consult Indigenous peoples in the area. In the two days after the court decision, Tahoe's stock fell over 33\% and remained at this level for the following month. In fact, Tahoe's stock never recovered to pre-July 5 levels.

In January 2019 Tahoe was purchased by Pan American Silver, despite the Escobal mine remaining closed following the 2017 court suspension. At the time of the sale, JCAP filed a complaint to the British Columbia Securities Commission requesting an investigation into whether Tahoe misstated and omitted material facts which were necessary for the Pan American shareholder vote. In particular, JCAP requested an investigation into whether (1) Tahoe failed to disclose that a court-ordered consultation process was met with significant opposition and conflict from the local Indigenous peoples, with two court proceedings challenging the consultations; (2) Tahoe made unrealistic statements about the mine reopening in December 2019; (3) Tahoe failed to disclose that the Constitutional Court nullified Tahoe's last remaining exploratory license; and (4) Tahoe failed to disclose that the Guatemalan government was ordered to reform laws in order to increase royalties going to communities affected by mining.

JCAP's complaint received significant news coverage highlighting the lack of disclosure of material facts in advance of the Pan American shareholder vote. ${ }^{43}$ The complaint and news coverage did not appear to impact Tahoe's stock prices as the transfer of ownership to Pan American Silver was well on its way. However, Pan American Silver immediately took steps to address the situation at the mine, including rescinding the estimated reopening date of December 2019, and stating that it will abide by the consultation mechanism ordered by the Constitutional Court of Guatemala. ${ }^{44}$ Pan American also settled the law suit launched by the farmers who were shot in the back by Tahoe security forces and provided an apology. ${ }^{45}$ These actions by Pan American show that the information provided in the JCAP complaints were material to the operations of the mine.

Over the five years during which JCAP filed its four complaints to securities regulators, Tahoe continued to hide significant issues with the Escobal mine. Over these years, the Tahoe stock suffered, dropping from $\$ 16.74$ USD before the 2013 violence against protestors and ending at \$4 USD, the price at which Pan American Silver purchased Tahoe in 2019.

\footnotetext{
${ }^{43}$ BIV “Activists file securities complaints against Vancouver miners" January 3, 2019); Toronto Star "Advocates call for investigations into Vancouver mining companies for reportedly omitting facts" (January 3, 2019); Financial Post "Complaints filed asking for investigation of Pan American and Tahoe Resources" (January 3, 2019).

${ }^{44}$ Financial Post, "Big win for foreign plaintiffs as Pan American settles Guatemala mine case" (July 31, 2019).

45 BIV, "Pan American closes Tahoe's six-year legal battle with Guatemalan protestors" (July 30, 2019); Financial Post, "Big win for foreign plaintiffs as Pan American settles Guatemala mine case” (July 31, 2019).
} 
The misstated facts and failures to disclose revealed by JCAP were material not only to Tahoe's immediate stock price in the days following each JCAP complaint, but also to its long-term financial performance from 2013-2019. The test for materiality is based on the substantial likelihood that a reasonable investor would take particular information into consideration in their decision to buy, sell, or hold stock. ${ }^{46}$ There should be no doubt as to the material nature of the community opposition and human rights abuses connected to Escobal. As we can see from the decisions by Norwegian Pension Fund and the Netherlands' Pensioenfonds to divest, Tahoe's failure to disclose information about human rights issues connected to Escobal was the stated reason for their decision to sell their holdings in Tahoe. These issues have also tied Tahoe up in lawsuits. Tahoe's own shareholders sued the company in various class action suits for damages resulting from its failures to disclose. ${ }^{47}$

Despite the ample evidence of materiality of these issues at Escobal mine, JCAP never received a response from the BC Securities Commission to any of its complaints and requests for investigation. JCAP is unaware whether the Commission even contacted Tahoe regarding these very public and troubling events at their mine. When the Constitutional Court of Guatemala suspended operations at Escobal in 2017 due to the lack of consultation with Indigenous people, JCAP followed up with the Commission on July 20, 2017. ${ }^{48}$ In this follow-up letter, JCAP pointed out that had Tahoe disclosed the information about the opposition from Indigenous people, investors would have been better informed. JCAP urged the Commission to investigate. We did not receive a reply. The lack of a response from the Commission is significant and speaks to the weak regulatory environment that mining companies rely upon when they choose to incorporate in Canada.

\section{Problems with the status quo: Inadequate Responses from Regulators and Vague National Instrument Guidance}

\subsection{Lack of Response from Regulators}

We know from access to information requests, that in some cases, after a JCAP complaint, Securities Commissions have asked the mining company to provide more information. However, none of our complaints have resulted in any subsequent disclosures by the companies.

\footnotetext{
${ }^{46}$ TSC Industries v. Northway, Inc., 426 U.S. 438 (1976), at 449.

${ }^{47}$ Cision PR Newswire, "Shareholder Class Action Filed Against Tahoe Resources" (July 12, 2017).

${ }^{48}$ Letter to British Columbia Securities Commission, July 20, 2017.
} 
We do not know why our complaints were ignored. Colleagues familiar with the securities systems, have informally speculated on a number of reasons.

(i) The complaint was deemed to be too insignificant given the priorities of the commission.

If this were the case, transparency on how commissions decide their priorities would be helpful. Those relying on the regulatory powers of the commissions, especially retail investors, should know whether the regulatory regime is robust enough to protect their interests.

(ii) Class action lawsuits against companies are a suitable mechanism for dealing with the fallout from lack of forthright disclosure.

If this were the case, commissions should make it clear that it will not take any enforcement action for breaches of continuous disclosure requirements. Of course, this would make a mockery of the legislation, which provides sanctions for failure to disclose promptly. In addition, class action law suits are time-consuming and not available in all cases.

(iii) The complaint was not taken seriously because it was filed by a Non-Government Organization, not a legitimate shareholder.

If this were the case, the commissions are making decisions based on personal whim, not on an objective evaluation of the impact of the information on the health of the business. Organizations working with local communities will know the actual situation on the ground best, and information from them should be highly valued, not ignored. The examples provided in this submission attest to the importance of local community knowledge.

(iv) The subject matter of the complaint - Indigenous rights, violence and breaches of human rights - are irrelevant to the operation of the business.

The empirical evidence we present in this submission adds to the growing recognition that issues relating to social conflict are material. We are not aware of any other empirical study that has shown otherwise.

\subsection{National Instrument Guidance}

The guidance currently provided by the National Instruments is clearly inadequate. NI 51-102 requires disclosure of material information, including the disclosure of any risk factors pertaining 
to "environment and health risks $[\ldots]$ economic or political conditions $[\ldots]$ and any other matter that would be most likely to influence an investor's decision to purchase securities." ${ }^{49}$ NI 43-101, which applies specifically to mining companies, requires that all technical reports filed by the company "include a general discussion on the extent to which the mineral resource estimates could be materially affected by any known environmental, legal, [...], socioeconomic, marketing, political, or other relevant factors." 50

These vague statements merely reinforce the security regulators' blind spots on disclosure of social license, Indigenous consent, and violence. Much more specific guidance is required.

\section{Recommendations}

We agree in general with the recommendations made by the Canadian Lawyers Association for International Human Rights ("CLAIHR") for disclosure of human rights impact. ${ }^{51}$

(i) Saliency is an appropriate lens for assessing the materiality of human rights impacts

Saliency uses a lens of risk to people as the starting point, not risk to the business as the materiality standard does, while acknowledging that where risk to people's human rights are the greatest, there is generally a convergence with risk to the business. More specifically, saliency focuses on those human rights impacts that are: (i) the most severe based on how grave and widespread the impact to human rights is and how difficult it would be to right the resulting harm; (ii) the potential of the human rights impacts to occur; (iii) the ability to avoid harm to human rights; and (iv) the impact of human rights on people, rather than risk to the business.

(ii) Ontario should keep pace with disclosure trends toward mandating reporting human rights due diligence and stakeholder impacts

The Taskforce has a unique opportunity to recognize: shifts in the expectations of the reasonable investor as well as the clarification of fiduciary duty away from a shareholder-centric view under Canadian corporate law; efforts to expand the conceptualization of materiality to include the perspective of a broader set of stakeholders; and monitor potential legislative proposals in Europe requiring businesses to carry out due diligence in relation to the potential human rights and

\footnotetext{
${ }^{49}$ Form 51-102F2, “Annual Information Form” at 138, part 2, s. 5.3; National Instrument 51-102: Continuous Disclosure Obligations, OSC NI 51-102 (Unofficial consolidation in effect 31 October 2011).

${ }^{50}$ Form 43-101F1, “Technical Report, item 14(d), National Instrument 43-101, OSC NI 43-101 (24 June 2011 ).

${ }^{51}$ CLAIHR, "Submission to the Capital Markets Modernization Taskforce”, September 7, 2020.
} 
environmental impacts of their operations and supply chains when proposing parameters of a mandatory ESG disclosure regime for Ontario.

In addition to the two recommendations from CLAIHR, JCAP recommends that there be specific stringent requirements for disclosure placed on extractive companies.

(iii) Extractive companies should have more explicit guidance related to disclosure of violence and human rights issues, and securities regulators should be required to enforce disclosures on these issues

Extractive activities such as mining and oil and gas are, by their very nature, disruptive. The human rights and Indigenous rights dimensions of their operations is a serious cause for concern. Disclosure requirements should take into account heightened interest in this particular area of business activity. The disclosure requirements set out for mining companies under NI 43-101 are examples of materiality being responsive to the distinctive requirements of the extractive sector. We submit that issues related to violence and human rights issues associated with a mine should fall into the same category. ${ }^{52}$

Mining companies incorporated in Canada have been associated with a great deal of conflict. For example, in 2013, a group of organizations from Latin America presented 23 case studies involving conflicts with Canadian mining companies in the region to the Inter-American Commission on Human Rights. ${ }^{53}$ In 2014, the Commission heard from a coalition of 29 civil society organizations from Canada, ${ }^{54}$ and again in 2015, from Catholic Bishops who criticized the practices of Canadian mining companies. ${ }^{55}$ Beginning in 2002, United Nations treaty bodies have urged Canada, specifically, to assume its responsibility to protect against human rights abuse outside its territory and to provide effective oversight regarding its companies' overseas operations, including through extraterritorial regulation. ${ }^{56}$ The Human Rights Committee of the United Nations stated in June 2015:

\footnotetext{
${ }^{52}$ International Corporate Accountability Roundtable, Knowing and Showing: Using U.S. Securities Laws to Compel Human Rights Disclosures (2013) at 15.

${ }^{53}$ Working Group on Mining and Human Rights in Latin America, El impacto de la minería canadiense en América Latina y la responsabilidad de Canadá, (2014).

${ }^{54}$ Canadian Network on Corporate Accountability, Human Rights, Indigenous Rights and Canada's Extra-territorial Responsibility, (2014).

${ }^{55}$ Posición de la Iglesia católica ante vulneración y abusos contra los derechos humanos de las poblaciones afectadas por las industrias extractivas en América Latina, (March 2015) [trans. "The position of the Catholic church in relation to the breaches and abuses of human rights of peoples affected by the extractive industries in Latin America] sponsored by Consejo Episcopal Latinoamericano (CELAM), Secretariado latinoamericano y del Caribe de Cáritas (SELACC), Confederación latinoamericana y caribeña de religiosos y religiosas (CLAR), Comisión amazónica de Conferencia Nacional de Obispos de Brasil (CNBB) and Red Eclesial Pan-amazónica (REPAM).

${ }^{56}$ See concerns from the Commission on Human Rights, the Committee on the Elimination of Racial Discrimination, and the Committee on the Rights of the Child: Commission on Human Rights, Adverse effects of the illicit movement and dumping of toxic and dangerous products and wastes on the enjoyment of human rights
} 
The State party [Canada] should (a) enhance the effectiveness of existing mechanisms to ensure that all Canadian corporations under its jurisdiction, in particular mining corporations, respect human rights standards when operating abroad; (b) consider establishing an independent mechanism with powers to investigate human rights abuses by such corporations abroad; and (c) develop a legal framework that affords legal remedies to people who have been victims of activities of such corporations operating abroad. ${ }^{57}$

JCAP's 2016 Canada Brand report, summarized above, is a systematic review of the extent of violence associated with Canadian mining companies in Latin America. Neither industry nor government has attempted a similar review.

The Canadian government recognizes the impact on share price of poor social responsibility performance in its policy on the extractive sector abroad. ${ }^{58}$

As the costs to business, including impacts on share price, of poor corporate behaviour become better known, the higher the demand will be from a broad spectrum of investors for credible reporting of CSR-related efforts, and the stronger the incentive for companies to improve their CSR performance.

(iv) There should be specific disclosure requirements relating to free, prior, and informed consent of Indigenous peoples (FPIC) for extractive companies, and securities regulators should be required to enforce these disclosure requirements.

This FPIC has been adopted by a number of industry bodies including the International Council on Mining and Metals, ${ }^{59}$ the International Financial Corporation, ${ }^{60}$ and the Equator Principles. ${ }^{61}$ Whether or not one agrees that the FPIC a standard is appropriate, or that it is required by law, the standard clearly impacts the success of a project. In Canada, we need only to look at the fate of the Northern Gateway Pipeline and the Transmountain Pipeline when there is opposition from Indigenous peoples. We provided the example of the lack of consent of the Bristol Bay Native

Report, Mission to Canada, 17-30 October 2002, (14 January 2003), E/CN.4/2003/56/Add.2, at para 126; Committee on the Elimination of Racial Discrimination, Concluding Observations, (25 May 2007), CERD/C/CAN/CO/18, at para 17; Committee on the Elimination of Racial Discrimination, Concluding Observations, CERD/C/CAN/CO/1920, (4 April 2012), at para 14; Committee on the Rights of the Child, Concluding Observations, (6 December 2012), CRC/C/CAN/CO/3-4, at para 29.

${ }^{57}$ Human Rights Committee, Concluding observations on the sixth periodic report of Canada, (23 June 2015), CCPR/C/CAN/CO/6, para 6.

58 Global Affairs Canada, "Doing Business the Canadian Way: A Strategy to Advance Corporate Social Responsibility in Canada's Extractive Sector Abroad",

${ }^{59}$ International Council on Mining and Metals, Indigenous Peoples and Mining: Position Statement (Accessed September 6, 2020).

${ }^{60}$ Earthworks, “IFC adopts FPIC standards, but will mining corporations implement?" (August 12, 2011).

${ }^{61}$ Herbert Smith Freehills, “Adoption of Equator Principles 4” (November 27, 2019). 
Corporation to the Pebble Mine in Alaska as information that impacted the share price of Northern Dynasty. In the case of Tahoe, the complete shutdown of the mine since July 2017 led to the demise of the company.

We realize that the extractive industry may raise a number of objections to requiring more stringent disclosures on human rights impacts and Indigenous consent. Our empirical research can shed light on two of the objections. First, will more stringent requirements place a burden on the industry? Second, does the existence of company Corporate Social Responsibility (CSR) policies make further disclosure redundant?

The first objection is that there will be an undue burden placed on companies to have to report specific instances of human rights impacts, such as violence associated with the project or lack of Indigenous consent. However, from JCAP's case studies, we cannot see a situation where registrants would suffer an extra burden for reporting on human rights issues. Any company operating in any context should be aware of the surrounding social environment, and if they are not, then perhaps there is a good argument for requiring companies to report on social issues.

In the case of Tahoe, for example, there would have been no additional burden at all. Tahoe knew information about the human rights situation at Escobal. This is evidenced by the plebiscite votes against the mine, the concerns vocalized by protestors, and the contents of the secret lawsuit against the government of Guatemala, in which Tahoe provided specific details on how protests had impeded its project. Tahoe had this information and chose not to disclose the extent of opposition to the mine to its investors. However, in the secret lawsuit against the government of Guatemala, Tahoe provided very specific details on how protests had impeded its project and how it could not even connect to the country's main power grid because of the protests.

In the case of Northern Dynasty, it clearly knew about the opposition of the Bristol Bay Native Corporation to its project, but it decided to hide that information from its investors.

The second objection is that reporting on Corporate Social Responsibility (CSR) initiatives should be sufficient disclosure. Most companies report extensive CSR initiatives on their websites and many provide colourful CSR reports every year. However, those measures are voluntary, and there is no monitoring of whether those measures are actually taken and whether those measures have reduced opposition of local communities.

In the case of Tahoe, for example, the company produced colourful web pages on measures it was supposedly taking to benefit local communities. The Council of Ethics of Norway inquired into Tahoe's CSR policies. Tahoe indicated to the Council that human rights were an "integral 
part of Tahoe Resources' ethical standards." 62 However, the human rights policy obtained by the Council indicated that the company's view on its obligations with respect to human rights was limited to respecting national laws and "cultural values." 63 The Council requested other parts of the company's policies and systems under human rights, but was advised that such policies would not be provided on the basis of confidentiality concerns. The same response was provided when the Council requested information relating a Social Performance Gap Analysis that was conducted on behalf of Tahoe in relation to the human rights impacts of its mine. ${ }^{64}$

With respect to Indigenous people, Tahoe stated that "in 2015, [wholly-owned subsidiary Minera San Rafael] engaged with indigenous communities in Guatemala that expressed an interest in the Escobal mine and during the year, more than 130 indigenous community members visited the Escobal Mine" and "indigenous peoples have participated in our Guatemalan avocado and coffee rust prevention programs and received donations of agricultural supplies and musical instruments." ${ }^{\prime 25}$ These meetings with individuals and the distribution of musical instruments do not amount to free, prior, and informed consent. ${ }^{66}$ Tahoe used its CSR literature to actually mislead investors into thinking that the Indigenous communities supported Tahoe's activities, whereas we know that Indigenous opposition shut down the mine and, eventually, shut down Tahoe itself.

\section{Concluding Thoughts}

There is a growing corporate awareness of the importance of weighing in on social issues - the corporate response to Black Lives Matter comes to mind - and some of the literature on this topic is alluded to in the submission of the Canadian Lawyers for International Human Rights. Unfortunately, much of the extractive industries are lagging behind - their engagement with communities consisting of self-promoting Corporate Social Responsibility initiatives, rather than a self-awareness of their complicity in violence and harm to Indigenous communities.

JCAP has approached the issue of human rights impact disclosure from a concern for the communities impacted, seeking some accountability through corporate acknowledgement of

\footnotetext{
${ }^{62}$ Council on Ethics to the Government Pension Fund Global, "Recommendation to exclude Tahoe Resources Inc. from the investment universe of the Government Pension Fund Global" (April 8, 2014) at 15.

${ }^{63}$ Council on Ethics to the Government Pension Fund Global, "Recommendation to exclude Tahoe Resources Inc. from the investment universe of the Government Pension Fund Global" (April 8, 2014) at 15.

${ }^{64}$ Justice and Corporate Accountability Project, "Request to Investigate Tahoe Resources for Failure to Disclose Material Information" (May 8, 2017) at 24.

${ }^{65}$ Securities Exchange Commission, "Form 6-K Tahoe Resources Inc. Report of Foreign Issuer" (March 10, 2017).

${ }^{66}$ Justice and Corporate Accountability Project, "Request to Investigate Tahoe Resources for Failure to Disclose Material Information" (May 8, 2017) at 14-17.
} 
these impacts. On the grand scale of things, simple disclosure does not do much for the communities- there is no remedy for the victims, the company is not required to do anything but disclose and non-disclosure is not sanctioned in practice.

However, we have shown empirically that the lack of disclosure does harm investors. ${ }^{67}$ Some investors - perhaps many investors - are not eager to be associated with companies that are in an unhealthy conflict with local communities. Other investors are harmed financially, because they do not have all the information needed to evaluate the risks associated with extractive industry shares.

In our view, it is incumbent on securities regulators and those providing disclosure guidance to address the disclosure problems in the extractive industries.

${ }^{67}$ Just as an example, an article published at the same time as this submission shows some fund managers going on site to confirm ESG reports by companies: Tommy Wilkes, Sijata Rao and Simon Jessop, "The fund managers, the sleuths and the mystery of the missing ESG" (Reuters, September 7, 2020) 


\section{Appendix A - Snapshot of Six Case Studies}

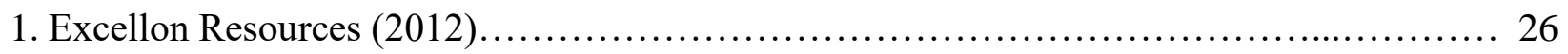

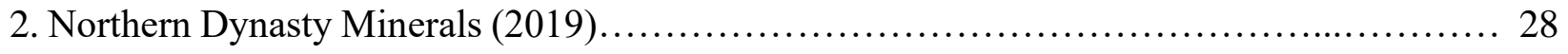

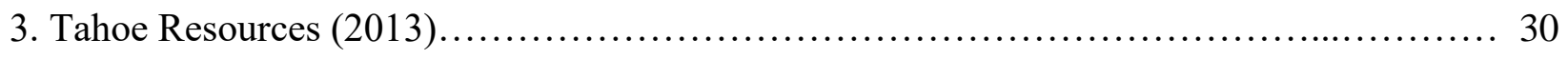

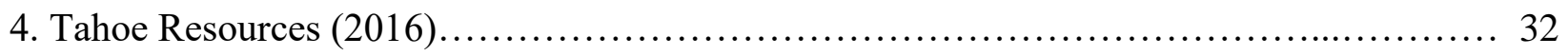

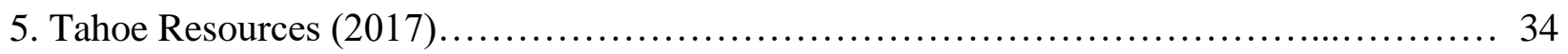

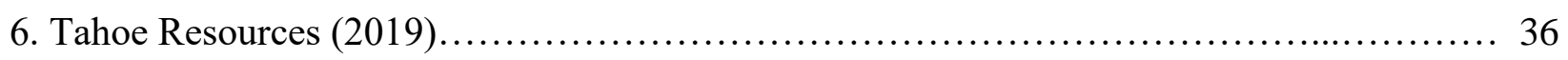




\section{Case Study: Excellon Resources (2012)}

\section{Background}

Excellon is a junior mineral resource company that operates primarily in Mexico. Excellon is incorporated in Ontario and listed on the Toronto Stock Exchange.

On July 8, 2012, the communal landowners of La Platosa mine in Mexico erected a blockade preventing Excellon Resources Inc., the operator of the mine, from accessing the site. The blockade was in response to Excellon's alleged breaches of the mine's lease agreement. The landowners notified Excellon that their continual non-compliance would result in a rescission of the contract.

Excellon is required as per section 75(1) of the Securities Act, R.S.O. 1990, c. S.5., to disclose material information about the mine in a timely manner.

On July 13, 2012, JCAP filed a complaint to the Ontario Securities Commission requesting an investigation into whether Excellon breached the Securities Act by failing to disclose the true nature of the conflict that led to the blockade: that the landowners considered the breached Agreement rescinded, thereby removing Excellon's access to the mine and jeopardizing the corporation's main source of revenue.

\section{Timeline of Excellon Press Releases ${ }^{68}$ and Media Attention ${ }^{69}$ about the Land Access Dispute}

Throughout the contract dispute, Excellon issued a series of press releases that discussed the blockade but failed to mention the possibility of a rescinded contract and loss of access to the mine. The contract dispute and its potential impact on Excellon's financial performance was covered in major news publications. In the seven business days after the news story broke, from July 9 - 20, Excellon's stock dropped by $27.54 \%$. In the five business days after JCAP filed its complaint, from July 13 - 20, Excellon's stock dropped by $10.17 \%$.

\footnotetext{
${ }^{68}$ Excellon's press releases: "Excellon intersects 55 metres of source-style mineralization $1.1 \mathrm{~km}$ northewst of Platosa Mine" (July 9, 2012); "Excellon reports on illegal action and union vote at La Platosa" (July 11, 2012); "Excellon provides update on illegal action at La Platosa Mine" (July 16, 2012).

${ }^{69}$ iPolitics, "Canadian-owned silver mine in Mexico blocked by farmers" (July 10 2012); Newswire, "Canada's Excellon Resources Threatens Arrests, Judicial Action as Mexican Landowners Demand Respect for Human Rights" (July 11, 2012); Stockhouse, "Excellon's stock plummets over 11\%"(July 16, 2012); Mining Weekly, "Securities Commission asked to investigate Excellon disclosures" (July 17, 2012).
} 


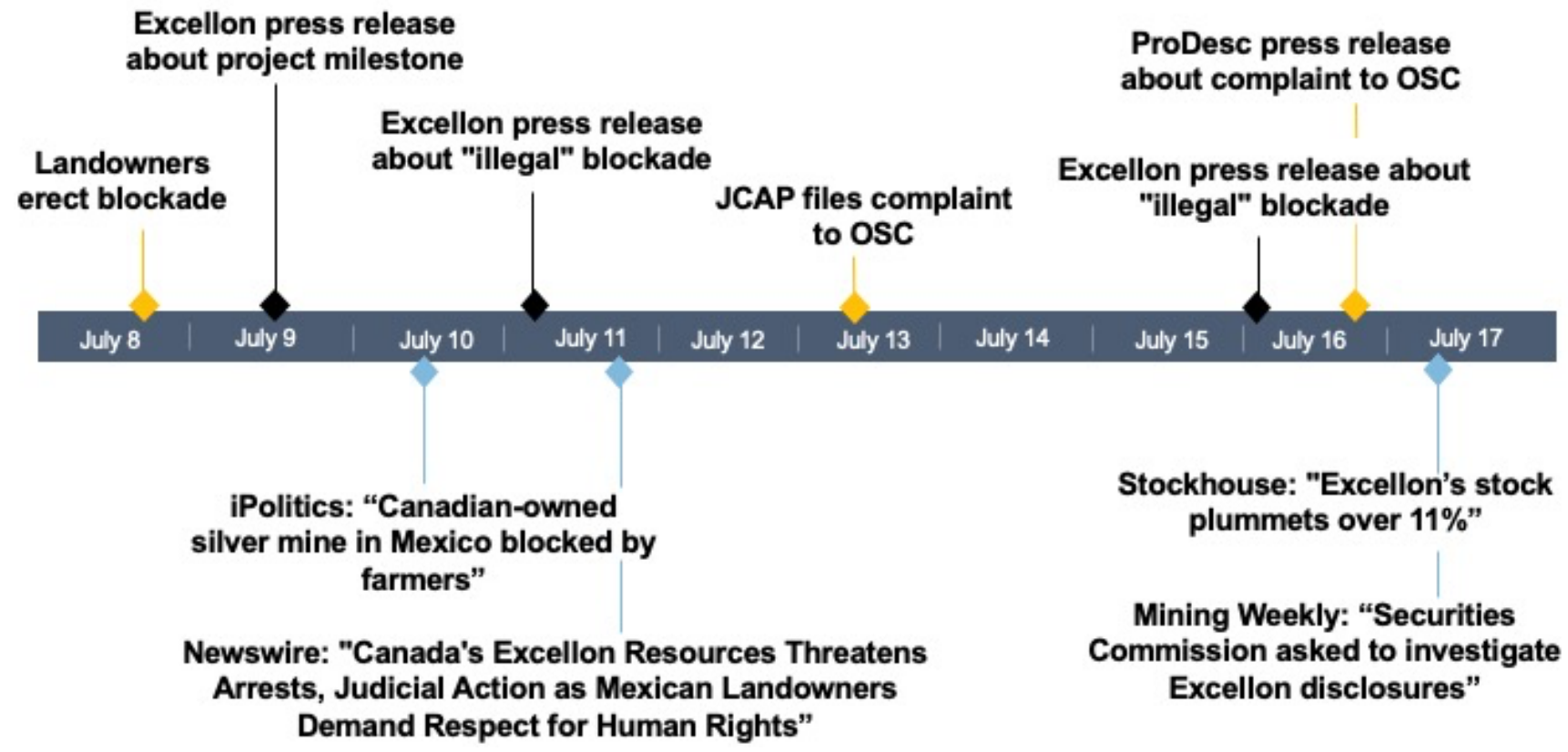

Excellon's stock prices started to dip on July 9, with news reports of the blockade at the mine. However, on Friday July 13, there was a small uptick to the stock price. On Monday July 16, ProDESC, an NGO supporting the communal land owners, issued a press release about the complaint. ${ }^{70}$ The drop in price began on Monday, when the markets re-opened and the contract dispute was revealed in major news publications and Excellon's failure to disclose the dispute was publicized.

\section{Changes in EXN Stock Price as News Reports on Blockade}

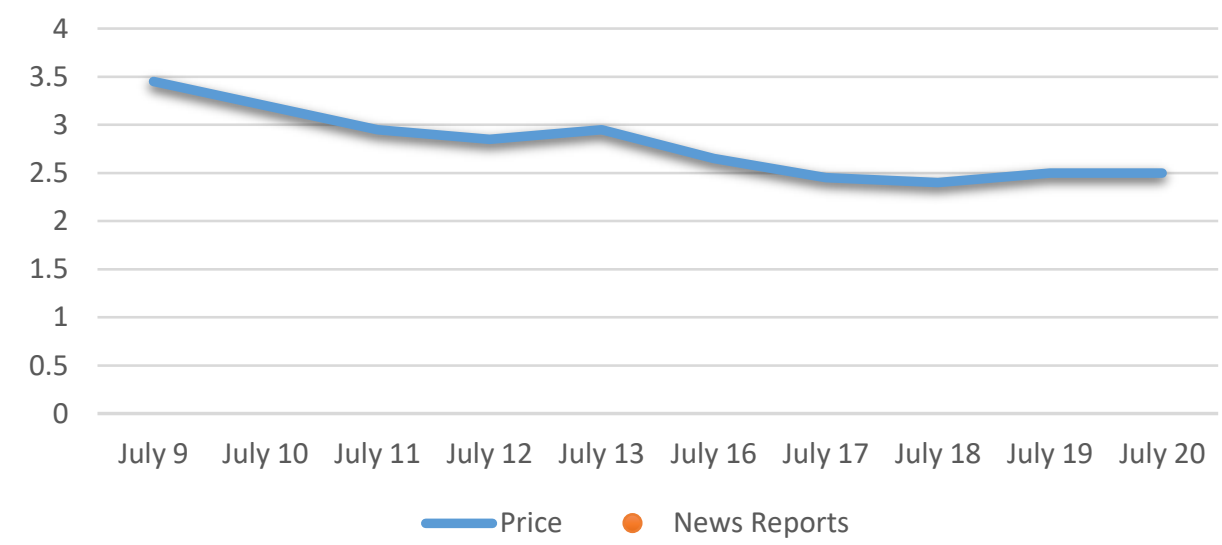

\footnotetext{
${ }^{70}$ Newswire, "Formal request submitted to Ontario Securities Commission for a full investigation of Excellon" (July $16,2012)$. 


\section{Case Study: Northern Dynasty Minerals (2019)}

\section{Background}

Northern Dynasty Minerals (NDM) is a mineral exploration company. NDM is headquartered in British Columbia and dual-listed on both Toronto (TSX:NDM) and New York stock (NYSE:NAK) exchanges.

On April 30, 2019, JCAP filed complaints on behalf of Earthworks to both the British Columbia Securities Commission and the US Securities and Exchange Commission (SEC) requesting an investigation into whether NDM had breached the Securities Act, RSBC 1990, c.418, in four ways with respect to the Pebble Mine project in Alaska:

1. Misrepresenting the amount of mineral resource available: the proposal was to mine only 1.17 billion tonnes as opposed to the 11 billion tonnes that NDM advertised.

2. Misrepresenting the project as "world class" and other claims which were not supported by the economic assessment, pre-feasibility study, or feasibility study.

3. Failing to disclose that the Bristol Bay Native Corporation (BBNC) owned the subsurface rights along the proposed gas pipeline and had refused to grant access to the pipeline.

4. Failing to disclose the BBNC's opposition to the project and failure to secure social license.

\section{Timeline of Media Attention About JCAP's Complaint and Pebble's Failure to Disclose and Misrepresentations ${ }^{71}$}

The four instances were covered in major news publications following JCAP's complaint to the SEC. In the seven business days after JCAP filed its complaint, NDM's NYSE stock (NYSE:NAK) dropped by $22.22 \%$ and TSX stock (TSX:NDM) dropped by $24.68 \%$.

\footnotetext{
${ }^{71}$ Mining Weekly, "Earthworks calls for investigation into Northern Dynasty over Pebble mine" (April 29, 2019); BNN Bloomberg, "Industry watchdog alleges Northern Dynasty misled investors" (April 30, 2019); Mining.com, "Environmental group alleges Northern Dynasty misled investors about Pebble project" (April 30, 2019); E\&E News, "Mining watchdogs accuse Pebble of misleading investors" (April 30, 2019); Mining News North, "ENGO calls for Pebble claims investigation" (May 3, 2019).
} 


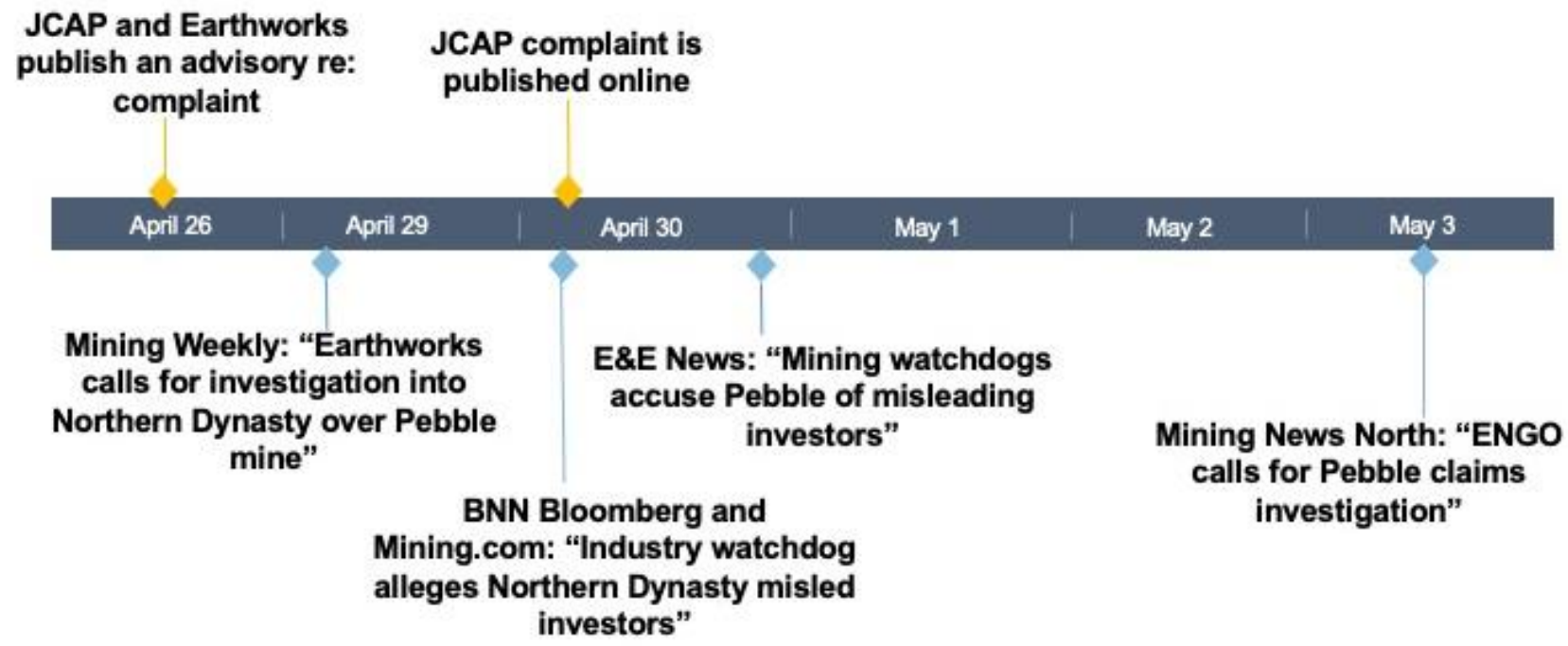

NDM's stock prices began to dip on April 29, which was the next business day following JCAP and Earthworks' public advisory about the complaint. The stock prices continued to drop following the complaint being published online and after additional media attention on April 30 . The drop in NDM's stock prices corresponds with the dates on which NDM's misrepresentations and failure to disclose material information were revealed in major news publications and the complaint.

\section{Changes in NYSE:NAK and TSX:NDM Stock Prices as News Reports on JCAP Complaint}

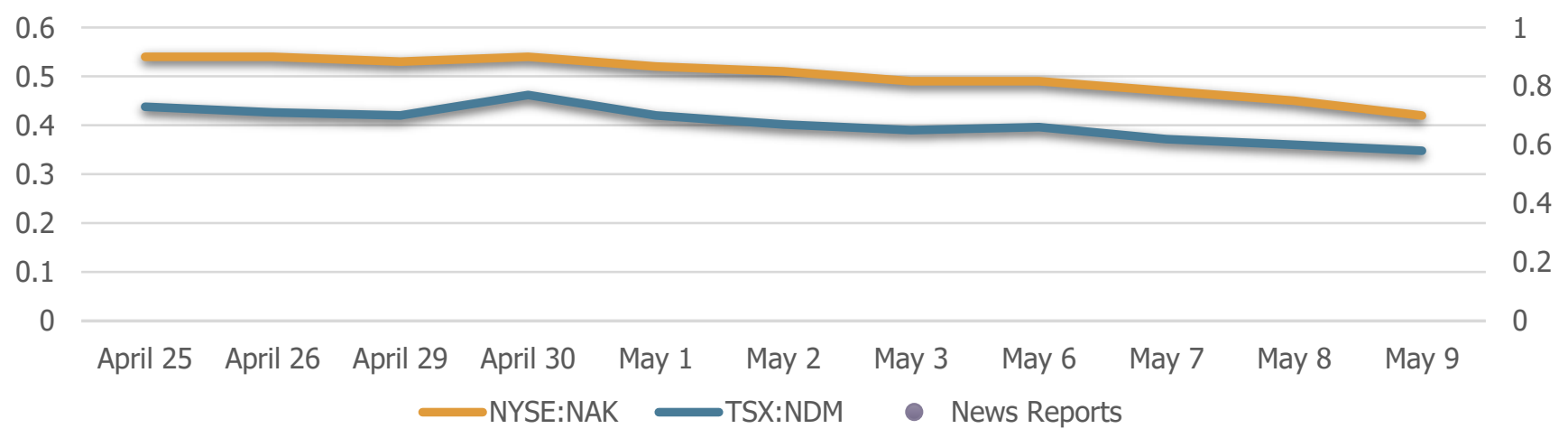




\section{Case Study: Tahoe Resources Inc. (2013)}

\section{Background}

Tahoe is a precious metal extraction company incorporated in British Columbia and headquartered in Reno, Nevada. The company's sole investment in 2013 was the Escobal mining project in Guatemala. Tahoe is dual-listed on the Toronto (TSX:THO) and New York stock exchanges (NYSE:TAHO).

On April 27, 2013, a group of community demonstrators against the Escobal project were gathered on private property. Tahoe later claimed that the protesters had become violent, although the company security camera revealed that heavily-armed Tahoe security opened fire at the group without provocation, shooting the protesters in the back as they fled the scene.

On May 30, 2013, JCAP filed a complaint to the Ontario Securities Commission requesting an investigation into whether Tahoe breached section 75(1) of the Securities Act, R.S.O. 1990, c. S.5., to disclose material information in a timely manner on two counts:

1. Tahoe downplayed the seriousness of the April 27 event and failed to disclose material information relating to the events.

2. Tahoe made misleading and incomplete statements to the press about the April 27 event and the criminal charges against Tahoe security personnel. For example, Tahoe released inaccurate statements downplaying their head of security being detained as he attempted to flee the country and charged with obstruction of justice and assault.

\section{Timeline of Tahoe Press Releases ${ }^{72}$ and News Reports Covering JCAP's Complaint ${ }^{73}$}

Following the shooting of protestors on April 27, Tahoe issued press releases and statements to the media that discussed the incident but failed to disclose the tactics used, the implication of Tahoe personnel, and elements of the criminal charges against personnel. These details were covered in major news publications, both before and after JCAP's complaint. In the three weeks following JCAP's complaint, Tahoe's stock on the NYSE dropped by $11.81 \%$.

\footnotetext{
72 Yahoo! Finance, “Tahoe Clarifies Reports Regarding Incidents Near Escobal Project” (May 1, 2013); Tahoe Spokesperson on CBC News, CBC Radio 1, May 4, 2013.

73 iPolitics, "Canadian mine's security staff detained as deadly protests trigger crackdown in Guatemala" (May 3, 2013); Guatemala Times, "Tahoe Resources Mining executive in Guatemala gives direct orders to kill protestors" (May 9, 2013); iPolitics, "Tahoe Resources fights allegations security chief ordered protestors killed" (May 12, 2013); Yahoo! Finance, "Complaint asks Ontario Securities Commission to Investigate Tahoe Resources After Wiretap Evidence Implicates Employees in Violence at Guatemala Mine" (June 3, 2013); Mining.com, “Ontario Securities Commission asked to probe Tahoe Resources for alleged violence in Guatemala" (June 3, 2013); Proactive Investors, "Tahoe trades down as complaint tied to violence at Guatemalan mine submitted to OSC" (June 3, 2013).
} 


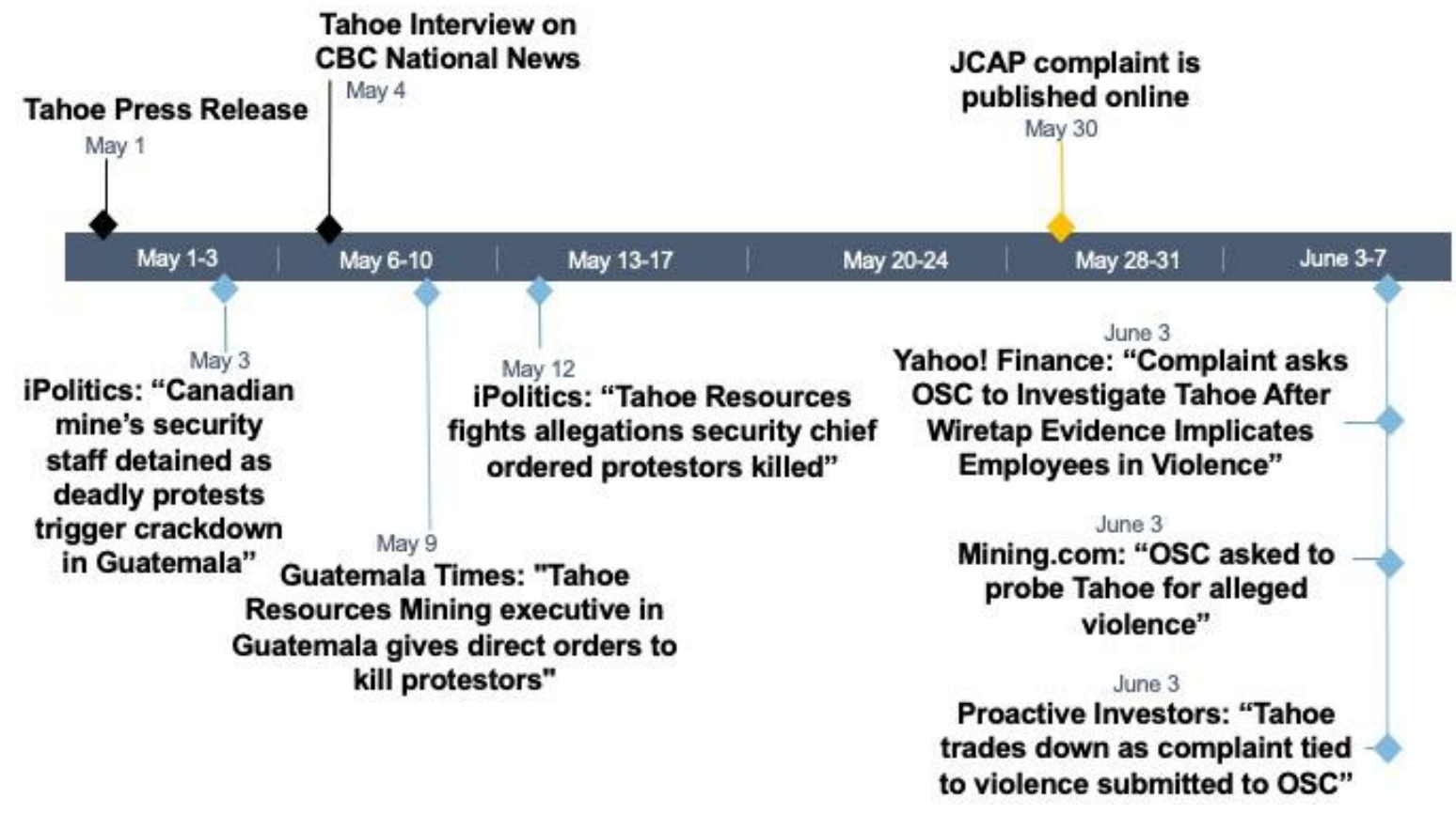

Tahoe's stock was on an upward trajectory until May 30, when the JCAP complaint was filed, at which point the stock began to slowly drop. The stock continued to drop throughout the remainder of June.

\section{Changes in the Tahoe Stock Price as News Reports on JCAP Complaint}

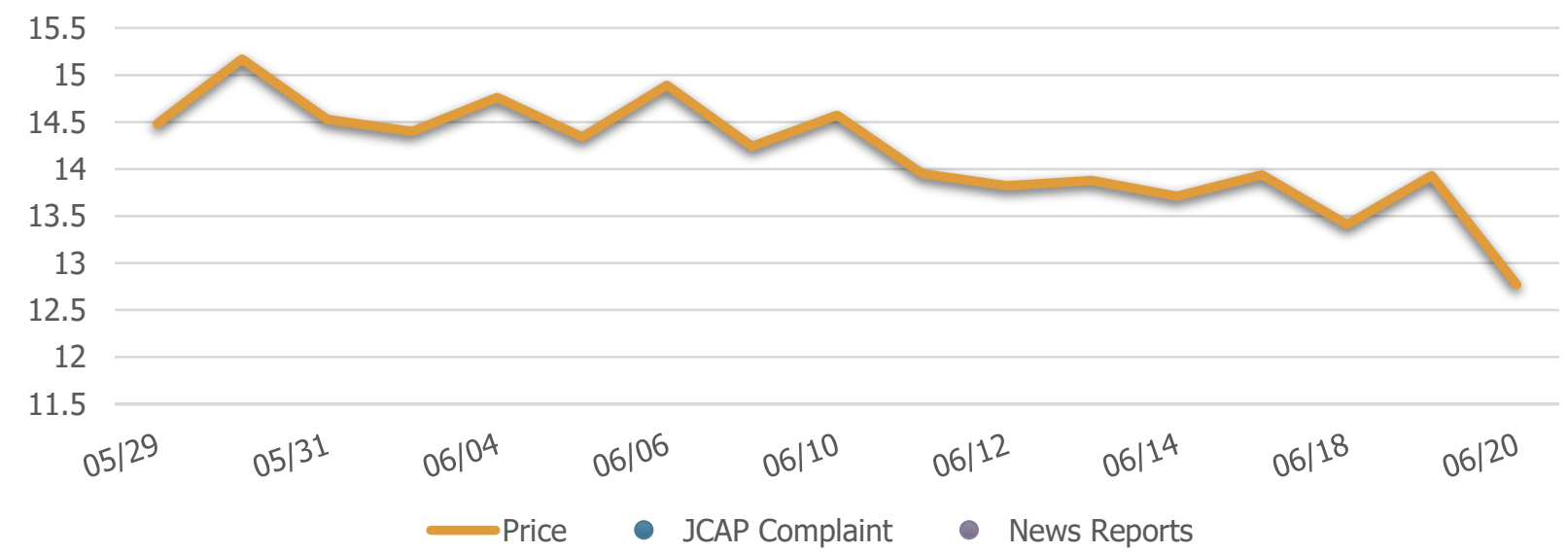




\section{Case Study: Tahoe Resources Inc. (2016)}

\section{Background}

Tahoe is a precious metal extraction company incorporated in British Columbia and headquartered in Reno, Nevada. The company's main asset is the Escobal mining project in Guatemala. Tahoe is duallisted on the Toronto (TSX:THO) and New York stock exchanges (NYSE:TAHO).

On August 8, 2016, on behalf of the Network in Solidarity with the People of Guatemala and the Catholic Church Committee for the Defense of Nature in Guatemala, JCAP filed a complaint to the US Securities and Exchange Commission (SEC) requesting an investigation into whether Tahoe misstated and omitted material facts about the following:

1. Tahoe misstated facts about community opposition to the Escobal mine and the associated risks this poses to the mine.

2. Tahoe failed to disclose that their subsidiary commenced a lawsuit against the Guatemalan government regarding protection from protestors as well as at least four lawsuits aimed at stopping and invalidating community votes about the mine.

3. Tahoe failed to disclose material information about human rights violations, including shooting at protestors and the kidnapping of a Xinca leader.

\section{Timeline of Media Attention About JCAP's Complaint and Tahoe's Failure to Disclose ${ }^{74}$}

Tahoe's misstatements and failure to disclose material facts were covered in major news publications following JCAP's complaint to the SEC. In the nine business days after the news story broke, Tahoe's TSX stock dropped by $13.24 \%$.

\footnotetext{
74 Toronto Star, "Canadian Company tried to stop referendum on mine in Guatemala" (August 11, 2016); Globe News Wire, "SEC Asked to Investigate Mining Company's Failure to Disclose Secret Lawsuits" (August 11, 2016). This story was also published on TD Direct Investing, Money News, Yahoo Finance, and Mining.com; Toronto Star, "Canadian Company tried to stop referendum on mine in Guatemala" (August 10, 2016).
} 


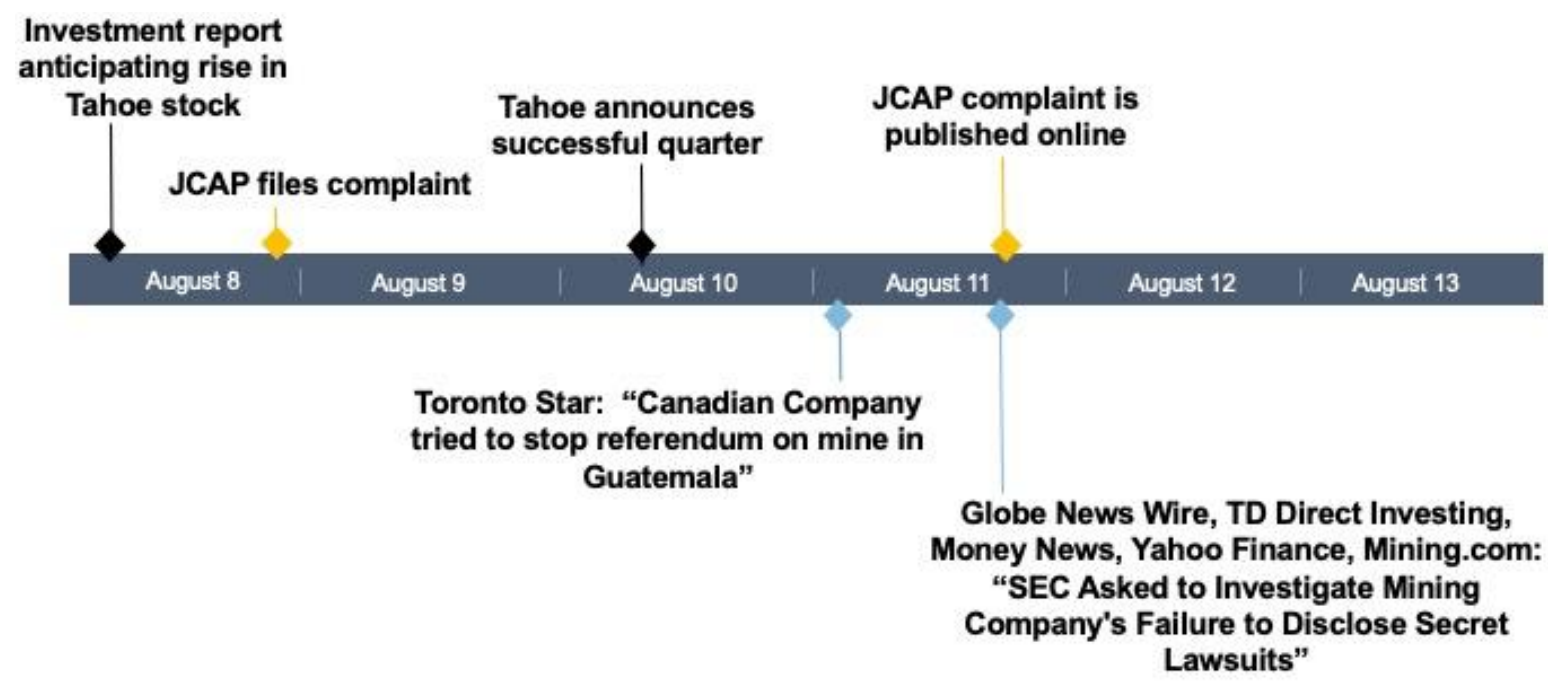

On August 8, 2016, Zacks Investment Research reported that analysts estimated an earnings beat, which would cause stock prices to rise following Tahoe's next quarterly report. ${ }^{75}$ On August 10, Tahoe announced a very successful quarter with earnings that beat expectations, resulting in a rise of nearly $6 \%{ }^{76}$ Despite Tahoe's much-anticipated and well-received quarterly report, the stock immediately began to fall on August 11 when JCAP's complaint

Changes in the Tahoe Stock Price as was publicized, and News Reports on JCAP Complaint continued to drop in the weeks that followed. There were no other announcements or events that would explain the sudden drop in the price.

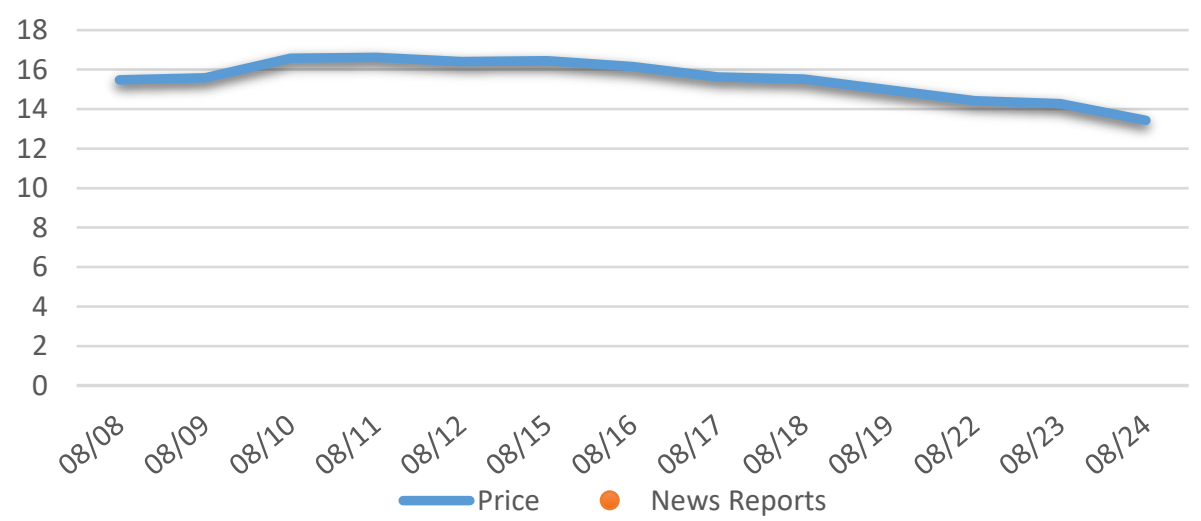

\footnotetext{
75 Zacks Investment Research, "Should You Sell Tahoe Resources (TAHO) Before Earnings?” (August 8, 2016).

76 Northern Miner, “Tahoe's Q2 earnings beat expectations" (August 10, 2016).
} 


\section{Case Study: Tahoe Resources Inc. (2017)}

\section{Background}

Tahoe is a precious metal extraction company incorporated in British Columbia and headquartered in Reno, Nevada. The Escobal mine in Guatemala is Tahoe's main asset. Tahoe is dual-listed on the Toronto (TSX:THO) and New York stock exchanges (NYSE:TAHO).

On August 8, 2016, JCAP filed a complaint to the US Securities and Exchange Commission (SEC) requesting an investigation into whether Tahoe misstated and omitted material facts. On May 8, 2017, JCAP filed this same complaint to the British Columbia Securities Commission (BCSC).

JCAP's complaint was about the following material facts:

1. Tahoe misstated facts about community opposition to the Escobal mine and the associated risks this poses to the mine.

2. Tahoe failed to disclose that their subsidiary commenced a lawsuit against the Guatemalan government regarding protection from protestors as well as at least four lawsuits aimed at stopping and invalidating community votes about the mine.

3. Tahoe failed to disclose material information about human rights violations, including shooting at protestors and the kidnapping of a Xinca leader.

\section{Timeline of News Reports Covering the Constitutional Court's Suspension $^{77}$}

JCAP did not publicize its May $8^{\text {th }}$ complaint to the BSCS and it did not receive media attention or result in a drop in Tahoe's stock. The complaint included information on the opposition of the Xinca Indigenous people to the mine. On July 5, 2017, the Constitutional Court in Guatemala suspended Tahoe's operations at the Escobal mine for failing to consult Indigenous peoples in the area. In the two days after the court decision, Tahoe's stock fell over 33\% and remained at this level for the following month. In fact, Tahoe's stock never recovered to pre-July 5 levels.

\footnotetext{
${ }^{77}$ Newswire, "Guatemalan Lower Court Issues Ruling On Tahoe's Mining License" (July 5, 2017); Mining.com, “Tahoe Resources forced to halt Escobal mine in Guatemala" (July 6, 2017); The Motley Fool, "Is it over for Tahoe Resources?" (July 10, 2017); The Guardian "The Canadian company mining hills of silver - and the people dying to stop it" (July 13, 2017).
} 


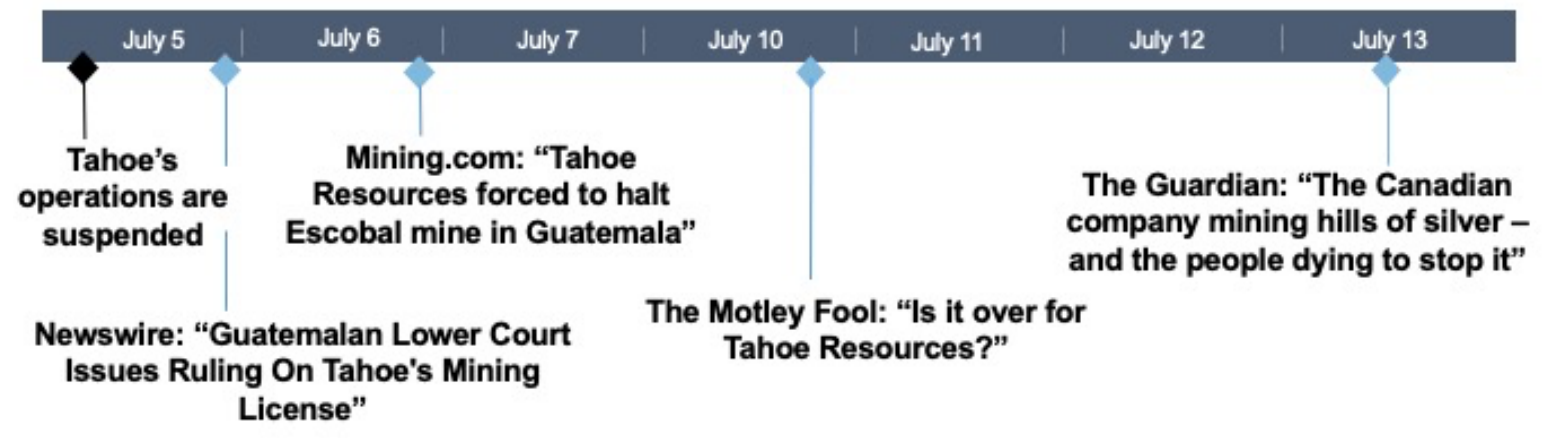

Although there was no change in the stock price when the May $8^{\text {th }}$ complaint was filed because investors were not notified by the media, the content of the complaint - in particular, Tahoe's failure to disclose the community opposition to the mine - was nonetheless material information to shareholders, as shown by the drastic and sustained drop in Tahoe's stock price after the court case.

\section{Changes in the Tahoe Stock Price After July 5 Court Suspension}

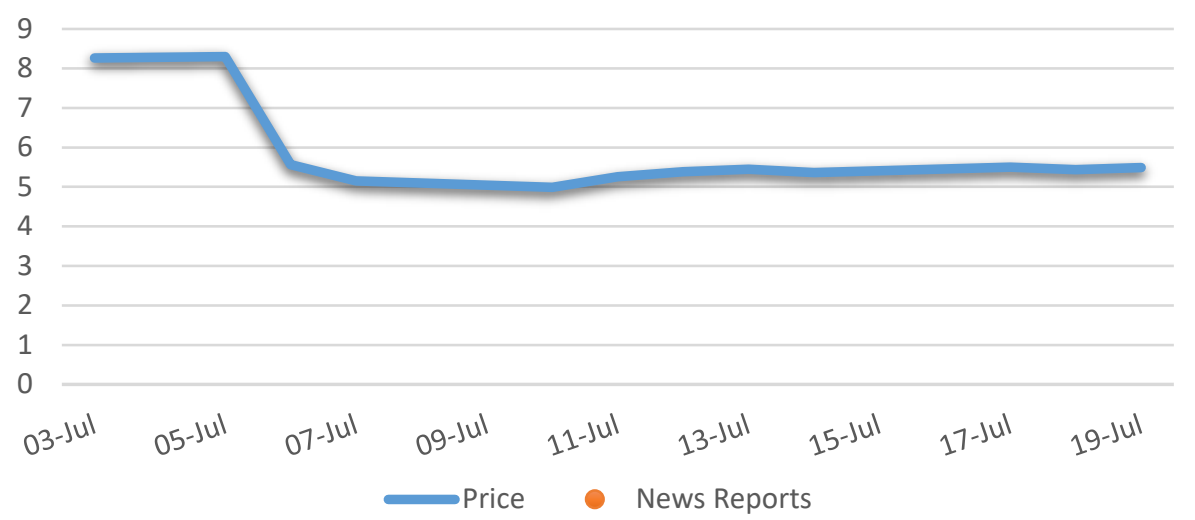




\section{Case Study: Tahoe Resources Inc. (2019)}

\section{Background}

Tahoe was a precious metal extraction company incorporated in British Columbia and headquartered in Nevada. The Escobal mine in Guatemala was Tahoe's main asset. Tahoe was dual-listed on the Toronto (TSX:THO) and New York stock exchanges (NYSE:TAHO).

On January 8, 2019, shareholders of Pan American Silver (TSX:PAAS) voted in favour to purchase Tahoe. In advance of the vote, JCAP filed a complaint to the British Columbia Securities Commission on January 3 requesting an investigation into whether Tahoe misstated and omitted material facts which were necessary for the shareholder vote. The material facts concerned the following:

1. Tahoe failed to disclose that the court-ordered consultation process was met with significant opposition and conflict from the local Indigenous peoples, with two court proceedings challenging the consultations.

2. Tahoe made misleading statements about the mine reopening in December 2019.

3. Tahoe failed to disclose that the Constitutional Court nullified Tahoe's last remaining exploratory license.

4. Tahoe failed to disclose that the Guatemalan government was ordered to reform laws in order to increase royalties going to communities affected by mining.

\section{Timeline of News Reports Covering JCAP's Complaint ${ }^{78}$}

JCAP's complaint received significant news coverage that highlighted the lack of disclosure of material facts in advance of the Pan American shareholder vote. The complaint and news coverage did not appear to impact Tahoe's stock prices as the transfer of ownership to Pan American Silver was well on its way.

However, the information on the problems with the consultation process was material to Tahoe's new shareholders at Pan American Silver, as it made statements to media outlets in response to JCAP's complaint, directly addressing the issue of consultation with Indigenous groups. Pan American's engagement with the news story indicates the company's awareness of the importance of these issues on shareholder decisions.

\footnotetext{
${ }^{78}$ BIV, “Activists file securities complaints against Vancouver miners” (January 3, 2019); Toronto Star, “Advocates call for investigations into Vancouver mining companies for reportedly omitting facts" (January 3, 2019); Financial Post, "Days before merger, complaints filed asking for investigation of Pan American and Tahoe Resources" (January 3, 2019); CIM, "B.C. Securities Commission asked to investigate Tahoe and Pan American days before acquisition vote" (January 3, 2019).
} 


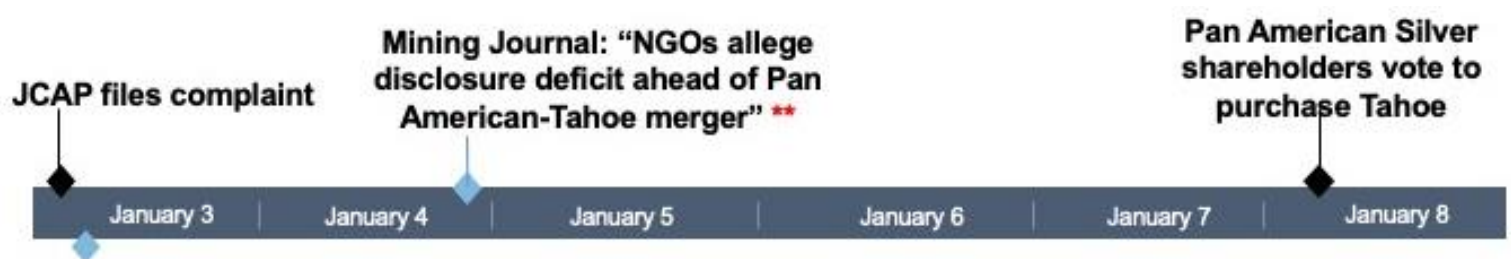

CIM: "B.C. Securities Commission asked to investigate Tahoe and Pan American days before acquisition vote" $* *$

Financial Post: "Days before merger, complaints filed asking for investigation of Pan American and Tahoe Resources"

** Stories in which Pan American Silver spokespersons commented

Toronto Star: "Advocates call for investigations into Vancouver mining companies for reportedly omitting facts" **

BIV: "Activists file securities complaints against Vancouver miners"

JCAP's complaint received strong media attention from business and mining industry outlets on the same day as its release, January 3 . The stock prices for both Tahoe and Pan American dropped the morning of January 4. By close of markets, they recovered to around the same closing price as the previous day. Given that the merger was already well into being finalized by January 3 , there was no impact on the share price beyond the dip on January 4.

Over the five years during which JCAP filed four complaints to securities regulators, Tahoe continued to fail to disclose significant issues with the Escobal mine. Over these years, the Tahoe stock suffered, dropping from $\$ 16.74$ USD before the 2013 violence against protestors and ending at \$4 USD, the price at which Pan American Silver purchased Tahoe in 2019.

\section{Changes in the Tahoe Stock Price After July 5 Court Suspension}

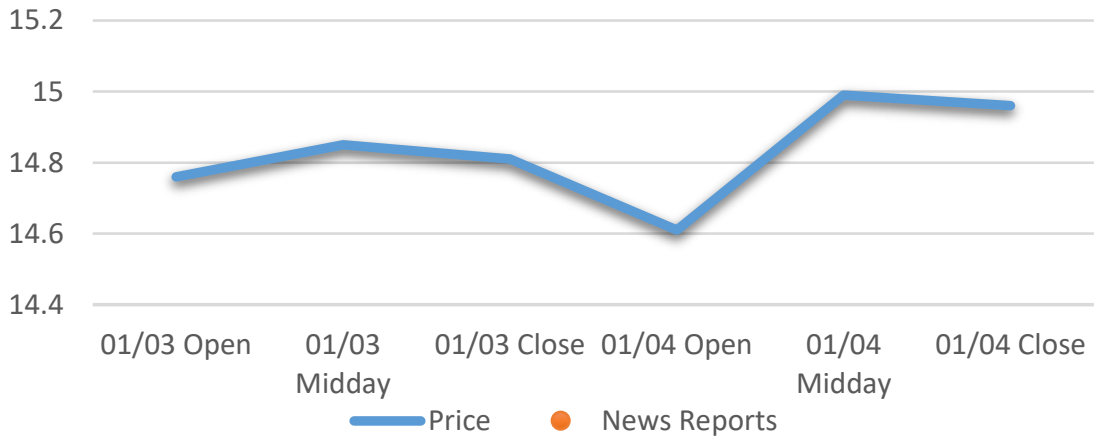

\section{Tahoe Stock Price From Violence in 2013 to Merger in 2019}

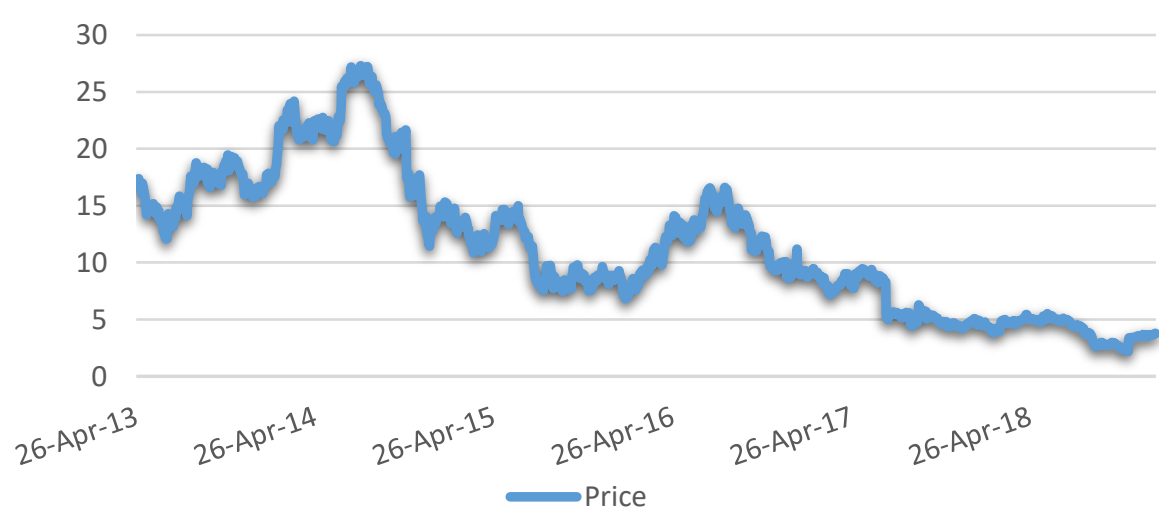




\section{Appendix B - Excerpt from Canada Brand report on disclosures made by companies with respect to violence associated with their mines}




\section{The "Canada Brand"}

\section{Violence and Canadian Mining \\ Companies in Latin America}

Released: October 24, 2016

(version 3: December 1, 2017)

Osgoode Hall Law School

York University

4700 Keele St.

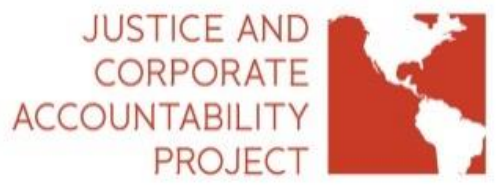

Toronto, Ontario

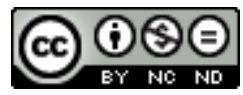

This work is licensed under the Creative Commons Attribution-Non Commercial-No Derivatives 4.0 International License. To view a copy of this license, visit http://creativecommons.org/licenses/by-nc-nd/4.0/.

39 | P a g e 


\section{TABLE OF CONTENTS}

$4 \quad$ Executive Summary

$7 \quad$ Preface

10 Part I: Observations about Violence and Criminalization

1. Violence by Country

2. Who is Affected?

3. Targeted Attacks

4. Sexual Violence

5. Protests

6. Criminalization

7. Violence is Accepted as a Part of Doing Business

23 Part II: Observations about Company Disclosures

1. Disclosure Research Findings

2. Larger companies tended to disclose less

27 Part III: Canadian Company Responsibility

1. If the company is following the laws of the foreign state, isn't that sufficient?

2. If the fault lies with the subsidiary in the foreign country, why should the corporate offices in Canada be responsible?

3. How can the company be held responsible when events are totally out of its control, like the assassination of a community member by an unknown assailant or the arrest of protesters by police?

4. How can the mining company be responsible for protecting its employees and community members, 
if the mine is located in an area where organized crime and cartels are active?

37 Part IV: Canadian Government Responsibility

1. Conduct of Canadian Companies

2. Securities Act Disclosure

42 Conclusion: A Call for Action

45 Appendix I: Methodology

1. Objectives

2. Methodological Approach

3. Limitations

51 Appendix II: Breakdown of Biographical Information and Categories of Violence

59 Appendix III: Summary of Research

100 Appendix IV: Comments from Companies 


\section{Executive Summary}

The Justice and Corporate Accountability Project has documented troubling incidents of violence associated with Canadian mining companies in Latin America. In general, neither the Canadian government nor industry are monitoring or reporting on these incidents.

\section{What we found about the degree of violence and criminalization from 2000-2015}

This Report documents incidents that are corroborated by at least two independent sources. We found:

- incidents involving 28Canadian companies;

- 44 deaths, 30 of which we classify as "targeted";

- 403 injuries, 363 of which occurred in during protests and confrontations;

- 709 cases of "criminalization", including legal complaints, arrests, detentions and charges; and

- a widespread geographical distribution of documented violence: deaths occurred in 11 countries, injuries were suffered in 13 countries, and criminalization occurred in 12 countries.

In addition, our research shows that Canadian companies that are listed on the Toronto Stock Exchange do not include reports of violence in their mandatory reports on company performance. Between 2000-2015:

- publicly listed companies reported $24.2 \%$ of the deaths and $12.3 \%$ of the injuries listed in this report; and

- larger companies tended to report incidents in general terms, using blanket statements, whereas smaller companies tended to report in more detail.

\section{What is significant about this study?}

This report on violence and criminalization associated with the Canadian mining industry in Latin America is the first to:

- compile information on reported violence over a 15-year period;

- name the companies involved and seek company comments on the incidents; and

- provide details and sources of the incidents, so that third-parties may reproduce our results. 


\section{PART II: OBSERVATIONS ABOUT COMPANY DISCLOSURES}

\footnotetext{
Tahoe Resources, a Canadian company with headquarters in Nevada, explains that being incorporated in Canada allows it to avoid stricter securities requirements in the United States.

"The regulatory and compliance costs to us under U.S. securities laws as a U.S. domestic issuer will be significantly more than the costs incurred as a Canadian foreign private issuer. ...we may lose our ability to rely upon exemptions from certain corporate governance requirements on U.S. stock exchanges that are available to foreign private issuers."
} 


\section{DISCLOSURE RESEARCH FINDINGS}

Companies listed on a stock exchange in Canada are required to disclose information pertaining to their mining projects on the SEDAR filing system of the Canadian Securities Administrators. Below, we analyze the disclosures made by the publicly listed companies. Private companies do not have to disclose any information so we have not counted them in the analysis.

Our research demonstrates a marked disparity between what was reported by local media sources, NGOs and academics, and what Canadian mining companies disclosed about the same events. The majority of these incidents went undisclosed by the Canadian parent companies. For example, companies disclosed $24.2 \%$ of reported incidents resulting in deaths and only $12.3 \%$ of injuries suffered by community members, mine workers, and police. When companies did report on violence related to their mining projects, the language used often did not describe the extent of the injuries suffered.

Company disclosure tended to be very general, and rarely included biographical information or total numbers of those affected by violence. Due to this lack of detail, our analysis of company disclosure of violent events looks at the number of incidents rather than the number of victims. Many of these events affected multiple individuals across a range of categories of violence. Further, some of the incidents that we researched were linked to private companies, or occurred at a time when a public company was not obligated to disclose on SEDAR (for example, shortly after the project had been bought by a non-Canadian company). Only the companies that were obligated to disclose are included in the disclosure data below.

\begin{tabular}{|l|l|l|l|}
\hline Category of Violence & $\begin{array}{l}\text { Reported } \\
\text { Incidents }\end{array}$ & $\begin{array}{l}\text { Disclosed } \\
\text { Incidents }\end{array}$ & $\begin{array}{l}\text { Disclosure } \\
\text { Rate (\%) }\end{array}$ \\
\hline Deaths & 33 & 8 & 24.2 \\
\hline Disappeared & 2 & 1 & 50 \\
\hline Injuries & 57 & 7 & 12.3 \\
\hline Sexual Violence & 2 & 0 & 0 \\
\hline $\begin{array}{l}\text { Warrants \& Legal } \\
\text { Complaints }\end{array}$ & 7 & 0 & 0 \\
\hline $\begin{array}{l}\text { Arrests, Detentions } \\
\text { \& Charges }\end{array}$ & 37 & 3 & 8.1 \\
\hline
\end{tabular}

Figure 6. The number of reported incidents and disclosed incidents in different categories of violence.

The numbers above represent company disclosure of the reported incident, and disclosure of the type of violence that was suffered (for example, deaths, injuries, or arrests). Often, companies mentioned an event like a protest or blockade, but did not disclose violence. This category of general disclosure is not represented in our disclosure statistics. 


\section{Larger companies tended to disclose less}

Our research demonstrates great variation in the level of detail in company disclosure documents. While details may be disclosed in other formats, like annual reports, larger companies like Barrick Gold Corp. tend to use blanket statements on SEDAR to indicate to investors that there is civil unrest in the region. Other companies report on the specific event, but provide an incomplete account of the violence that occurred, when compared with other sources. For example, when police attempted to break up a 2015 blockade of B2Gold's El Limón mine in Nicaragua, there were reports of 31 injuries and the death of a police officer. B2Gold, fulfilling its disclosure requirements, published a news release that omitted mention of injuries to demonstrators:

On October 17, 2015, the Government of Nicaragua instructed the police to remove the illegal blockade, arrest those responsible for prior violent actions that left one police officer deceased and others injured, and establish civil order in the town of El Limón. The illegal blockade was successfully removed by the police and workers were able to return to work. On October 19, 2015, normal operations resumed at the mine. ${ }^{79}$

In contrast, smaller companies with fewer projects tended to report in more detail about violent events occurring in relation to their mines. For example, in 2013, the Escobal mine in Guatemala was Tahoe Resource's only project. Our researchers found reports of five deaths, 28 injuries, 56 arrests and charges laid, and one state of emergency linked to the Escobal mine, which occurred over 10 separate incidents. Tahoe disclosed details on six of the 14 incidents, although the information provided did not always match other credible reports. For example, in the following News Release (excerpt), Tahoe describes an incident outside its Escobal project in April 2013:

During the evening shift change of Saturday, April 27, 2013, a protest involving approximately 20 people armed with machetes turned hostile. The Escobal security force used tear gas and rubber bullets to repel the protestors at the mine gate. These individuals left the area following this incident and some were treated at hospitals and released. Our investigation has shown that only non-lethal measures were taken by our security. We regret any injuries caused by rubber bullets, but we take the protection of our employees and the mine seriously. ${ }^{80}$

\footnotetext{
${ }^{79}$ B2Gold MD\&A (Management Discussion and Analysis] November 12, 2015, p. 12. Source: SEDAR

80 Tahoe Resources News Release, May 1, 2013. Source: SEDAR
} 
This description varies greatly from video footage of the event, and from what was revealed in a wiretap of the mine's head of security. JCAP published a more accurate version of events in a 2016 report to the US Securities and Exchange Commission:

Unbeknownst to Tahoe, telephone conversations of their head of security, Alberto Rotondo, had been wiretapped due to suspicions of his involvement in a prior incident of violence. The wiretap demonstrates that Rotondo ordered the shooting of the protesters and then conspired to cover up the evidence and fabricate a story of the attack. Security video obtained from the company shows that there were about twenty protesters, but they made no attempt to enter the open gate nor is there any indication that traffic was impeded. ${ }^{81}$ They were not acting in a hostile manner nor shouting slogans. The video first shows puffs of dust as bullets hit the ground near the protesters, then heavily armed security personnel with shields, helmets and bullet proof vests charge out of the mine grounds. The guards stand outside of the gate of the mine and shoot fleeing farmers in their backs. Seven of the protesters were injured. Rotondo was ultimately arrested in Guatemala in connection with the shooting. After being committed to trial in Guatemala he was placed under house arrest in December 18, 2014. In November 2015 he fled to Peru. He was recaptured in January 22, 2016 and five Guatemalan police officers have been arrested in connection with his escape. ${ }^{82}$

The trends that we observed in how companies disclose violence at or near their mines shines a light on the standards set by Canadian securities regulations, which only require companies to disclose what has, or may result in, a change to the market value of their shares.

It is unlikely that any individual mining conflict would impact the cost of shares of large companies that have several operations in different global regions (like Barrick Gold). As such, these companies would not be obligated to disclose any particular incident. Inversely, a smaller company with only one or two operating mines (like Tahoe) may have to disclose an incident that has disrupted its operations. A stoppage in operations for a smaller company is more likely to affect the market value of share.

Thus, larger companies with more mines, which are likely to generate greater risk of conflict, are held to a lower standard of disclosure than smaller companies. Canadian disclosure regulations allow for the most prolific mining companies to remain silent on violence related to their projects.

\footnotetext{
${ }^{81}$ To watch the video: Tahoe On Trial, Security Footage Outside Escobal Mine, (2016), online: <https://perma.cc/QGL4-2LZV>; To read wiretap transcript: Affidavit of Roger Barany, January 21, 2015, filed in the matter of Garcia v. Tahoe Resources, Supreme Court of British Columbia, No. S-144766, online: <https://perma.cc/QXH8-SGYL>.

${ }^{82}$ See the following reports from the Guatemalan paper: La Hora, "Juez podría enviar a juicio a Alberto Rotondo," (December 17, 2014), online: <https://perma.cc/RHU2-MC8Q>; La Hora, "Capturan a Alberto Rotondo," (January 22, 2016), online: <https://perma.cc/Z853-GLMP>; La Hora, "Señalan a policías por escape de Rotondo," (February 19, 2016), online: <https://perma.cc/3NEN-ARW5>.
} 